NASA/TM-2007-214955

AIAA-2007-4721

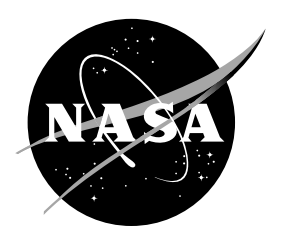

\title{
Ultra-Lightweight Hybrid Thin-Film Solar Cells: A Survey of Enabling Technologies for Space Power Applications
}

Aloysius F. Hepp, Jeremiah S. McNatt, Sheila G. Bailey, and John E. Dickman

Glenn Research Center, Cleveland, Ohio

Ryne P. Raffaelle, Brian J. Landi, Annick Anctil, and Roberta DiLeo

Rochester Institute of Technology, Rochester, New York

Michael H.-C. Jin, Chun-Young Lee, and Theresa J. Friske

University of Texas at Arlington, Arlington, Texas

Sam-S. Sun, Cheng Zhang, S. Choi, Abram Ledbetter, Kang Seo, and Carl E. Bonner Norfolk State University, Norfolk, Virginia

Kulbinder K. Banger and Stephanie L. Castro

Ohio Aerospace Institute, Brook Park, Ohio

David Rauh

EIC Laboratories, Inc., Norwood, Massachusetts 


\section{NASA STI Program . . . in Profile}

Since its founding, NASA has been dedicated to the advancement of aeronautics and space science. The NASA Scientific and Technical Information (STI) program plays a key part in helping NASA maintain this important role.

The NASA STI Program operates under the auspices of the Agency Chief Information Officer. It collects, organizes, provides for archiving, and disseminates NASA's STI. The NASA STI program provides access to the NASA Aeronautics and Space Database and its public interface, the NASA Technical Reports Server, thus providing one of the largest collections of aeronautical and space science STI in the world. Results are published in both non-NASA channels and by NASA in the NASA STI Report Series, which includes the following report types:

- TECHNICAL PUBLICATION. Reports of completed research or a major significant phase of research that present the results of NASA programs and include extensive data or theoretical analysis. Includes compilations of significant scientific and technical data and information deemed to be of continuing reference value. NASA counterpart of peer-reviewed formal professional papers but has less stringent limitations on manuscript length and extent of graphic presentations.

- TECHNICAL MEMORANDUM. Scientific and technical findings that are preliminary or of specialized interest, e.g., quick release reports, working papers, and bibliographies that contain minimal annotation. Does not contain extensive analysis.

- CONTRACTOR REPORT. Scientific and technical findings by NASA-sponsored contractors and grantees.
- CONFERENCE PUBLICATION. Collected papers from scientific and technical conferences, symposia, seminars, or other meetings sponsored or cosponsored by NASA.

- SPECIAL PUBLICATION. Scientific, technical, or historical information from NASA programs, projects, and missions, often concerned with subjects having substantial public interest.

- TECHNICAL TRANSLATION. Englishlanguage translations of foreign scientific and technical material pertinent to NASA's mission.

Specialized services also include creating custom thesauri, building customized databases, organizing and publishing research results.

For more information about the NASA STI program, see the following:

- Access the NASA STI program home page at http://www.sti.nasa.gov

- E-mail your question via the Internet to help@sti.nasa.gov

- Fax your question to the NASA STI Help Desk at 301-621-0134

- Telephone the NASA STI Help Desk at 301-621-0390

- Write to: NASA Center for AeroSpace Information (CASI) 7115 Standard Drive Hanover, MD 21076-1320 
NASA/TM-2007-214955

AIAA-2007-4721

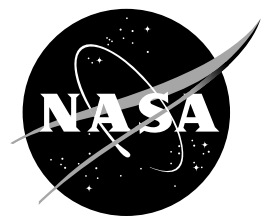

Ultra-Lightweight Hybrid Thin-Film Solar Cells: A Survey of Enabling Technologies for Space Power Applications

Aloysius F. Hepp, Jeremiah S. McNatt, Sheila G. Bailey, and John E. Dickman Glenn Research Center, Cleveland, Ohio

Ryne P. Raffaelle, Brian J. Landi, Annick Anctil, and Roberta DiLeo

Rochester Institute of Technology, Rochester, New York

Michael H.-C. Jin, Chun-Young Lee, and Theresa J. Friske

University of Texas at Arlington, Arlington, Texas

Sam-S. Sun, Cheng Zhang, S. Choi, Abram Ledbetter, Kang Seo, and Carl E. Bonner

Norfolk State University, Norfolk, Virginia

Kulbinder K. Banger and Stephanie L. Castro

Ohio Aerospace Institute, Brook Park, Ohio

David Rauh

EIC Laboratories, Inc., Norwood, Massachusetts

Prepared for the

Fifth International Energy Conversion Engineering Conference and Exhibit

sponsored by the American Institute of Aeronautics and Astronautics

St. Louis, Missouri, June 25-27, 2007

National Aeronautics and

Space Administration

Glenn Research Center

Cleveland, Ohio 44135 


\section{Acknowledgments}

All of the authors gratefully acknowledge NASA Glenn Research Center for financial support. Michael H.-C. Jin thanks University of Texas at Arlington and the Korea Science and Engineering Foundation for financial support. We thank Jon Cowen (Case Western Reserve University), Prof. Jerry Harris (Northwest Nazarene University), Prof. Jung-Il Jin (Korea University), Dr. SungHoon Joo (Korea University), Dr. Krishna Mandal (EIC Laboratories, Inc.), Robert Newton (Techni-Met, Inc.), Prof. John Reynolds (Univ. of Florida), David Scheiman (Essential Research, Inc.) and Dr. Fei Wang (EIC Laboratories, Inc.) for samples, measurements and/or technical discussions.

This report is a formal draft or working paper, intended to solicit comments and ideas from a technical peer group.

Level of Review: This material has been technically reviewed by technical management.

Available from

NASA Center for Aerospace Information 7115 Standard Drive

Hanover, MD 21076-1320
National Technical Information Service 5285 Port Royal Road Springfield, VA 22161 


\title{
Ultra-Lightweight Hybrid Thin-Film Solar Cells: A Survey of Enabling Technologies for Space Power Applications
}

\author{
Aloysius F. Hepp, Jeremiah S. McNatt, Sheila G. Bailey, and John E. Dickman \\ National Aeronautics and Space Administration \\ Glenn Research Center \\ Cleveland, Ohio 44135 \\ Ryne P. Raffaelle, Brian J. Landi, Annick Anctil, and Roberta DiLeo \\ Rochester Institute of Technology \\ Rochester, New York 14623 \\ Michael H.-C. Jin, Chun-Young Lee, and Theresa J. Friske \\ University of Texas at Arlington \\ Arlington, Texas 76019 \\ Sam-S. Sun, Cheng Zhang, S. Choi, Abram Ledbetter, Kang Seo, and Carl E. Bonner \\ Norfolk State University \\ Norfolk, Virginia 23504 \\ Kulbinder K. Banger and Stephanie L. Castro \\ Ohio Aerospace Institute \\ Brook Park, Ohio 44142 \\ David Rauh \\ EIC Laboratories, Inc. \\ Norwood, Massachusetts 02062
}

\begin{abstract}
The development of hybrid inorganic/organic thin-film solar cells on flexible, lightweight, space-qualified, durable substrates provides an attractive solution for fabricating solar arrays with high mass specific power (W/kg). Next generation thin-film technologies may well involve a revolutionary change in materials to organic-based devices. The high-volume, low-cost fabrication potential of organic cells will allow for square miles of solar cell production at one-tenth the cost of conventional inorganic materials. Plastic solar cells take a minimum of storage space and can be inflated or unrolled for deployment. We will explore a cross-section of in-house and sponsored research efforts that aim to provide new hybrid technologies that include both inorganic and polymer materials as active and substrate materials. Research at University of Texas at Arlington focuses on the fabrication and use of poly(isothianaphthene-3,6-diyl) in solar cells. We describe efforts at Norfolk State University to design, synthesize and characterize block copolymers. A collaborative team between EIC Laboratories, Inc. and the University of Florida is investigating multijunction polymer solar cells to more effectively utilize solar radiation. The National Aeronautics and Space Administration (NASA)/Ohio Aerospace Institute (OAI) group has undertaken a thermal analysis of potential metallized substrates as well as production of nanoparticles of CuInS $\mathrm{C}_{2}$ and $\mathrm{CuInSe} \mathrm{in}_{2}$ good yield at moderate temperatures via decomposition of single-source precursors. Finally, preliminary work at the Rochester Institute of Technology (R.I.T.) to assess the impact on performance of solar cells of temperature and carbon nanotubes is reported. Technologies that must be developed to enable ultra-lightweight solar arrays include: monolithic interconnects, lightweight array structures, and new ultra-light support and deployment mechanisms. For NASA applications, any solar cell or array technology must not only meet weight and AM0 efficiency goals, but also must be durable enough to survive launch conditions and space environments.
\end{abstract}

\section{Nomenclature}

AM0 air mass zero (space solar spectrum)

CNT carbon nanotube 


$\begin{array}{ll}\text { CNV } & \text { cyanovinylene } \\ \text { CPPV } & \text { (carbonized) poly-p-phenylenevinylene } \\ \text { CTE } & \text { coefficient of thermal expansion } \\ \text { CuInS(e) } & \text { copper indium disulf(selen)ide } \\ \text { CVDP } & \text { chemical vapor deposition (polymerization) } \\ \text { D/A } & \text { donor/acceptor } \\ \text { DBAB } & \text { donor-bridge-acceptor-bridge block co-polymer } \\ \text { FTIR } & \text { Fourier transform infrared } \\ \text { GRC } & \text { NASA Glenn Research Center } \\ \text { HOMO } & \text { highest occupied molecular orbital } \\ \text { HRTEM } & \text { high-resolution transmission electron microscope } \\ \text { ITO } & \text { indium tin oxide } \\ \text { ITO } & \text { indium tin oxide; typically 90\% In }{ }_{2} \mathrm{O}_{3}, 10 \% \mathrm{SnO}_{2} \text { by weight } \\ J_{s c} & \text { short-circuit current } \\ \text { LUMO } & \text { lowest unoccupied molecular orbital } \\ \text { MWNT } & \text { multi-wall (carbon) nanotube } \\ \text { NASA } & \text { National Aeronautics and Space Administration } \\ \text { NSU } & \text { Norfolk State University } \\ \text { OAI } & \text { Ohio Aerospace Institute } \\ \text { OBHSC } & \text { ordered bulk heterojunction solar cell } \\ \text { OPV } & \text { organic photovoltaics } \\ \text { OSC } & \text { organic solar cell } \\ \text { P3HT } & \text { poly-3-hexylthiophene } \\ \text { PCBM } & \text { [6,6]-phenyl-[C } 61 \text {-butyric acid methyl ester } \\ \text { PCE } & \text { power conversion efficiencies } \\ \text { PE-CVD } & \text { plasma-enhanced chemical vapor deposition } \\ \text { PEDOT } & \text { poly(3,4-ethylenedioxythiophene) } \\ \text { PITN } & \text { poly(isothianaphthene) } \\ \text { PL } & \text { photoluminescence } \\ \text { PSS } & \text { poly(styrene sulfonate) } \\ \text { QD } & \text { quantum dots } \\ \text { R.I.T. } & \text { Rochester Institute of Technology } \\ \text { RO-PPV } & \text { alkyloxy-derivatized poly-p-phenylenevinylene } \\ \text { SEM } & \text { scanning electron microscopy } \\ \text { SF-PPV } & \text { alkyloxy-sulfone derivatized poly-p-phenylenevinylene } \\ \text { SWNT } & \text { single-wall (carbon) nanotube } \\ \text { TGA } & \text { thermogravimetric analysis } \\ \text { TOPO } & \text { trioctylphosphine oxides } \\ \text { UF } & \text { University of Florida } \\ \text { UTA } & \text { University of Texas at Arlington } \\ V_{o c} & \text { open-circuit voltage } \\ & \end{array}$

\section{Introduction}

Solar array designs have undergone a steady evolution since the Vanguard 1 satellite. Early satellites used silicon solar cells on honeycomb panels that were body mounted to the spacecraft. Early space solar arrays only produced a few hundred watts of power. Satellites today require low-mass solar arrays that produce several kilowatts of power. Several new solar array structures have been developed over the past forty years to improve the array specific power and reduce the stowed volume during launch. The solar arrays presently in use can be classified into six categories: (1) body-mounted arrays; (2) rigid panel planar arrays; (3) flexible panel array; (4) flexible roll-out arrays; (5) concentrator arrays; and (6) high temperature/intensity arrays. ${ }^{1}$

In addition, several proposed space missions have put other constraints on the solar arrays. Several proposed Earth orbiting missions designed to study the sun require "electrostatically clean" arrays. Inner planetary missions and mission to study the Sun within a few solar radii require solar arrays capable of withstanding temperatures above $450{ }^{\circ} \mathrm{C}$ and functioning at high solar intensities. Outer planetary missions require solar arrays that can 
function at low solar intensities and low temperatures. In addition to the near-sun missions, missions to Jupiter and its moons also require solar arrays that can withstand high radiation levels.

There is currently a tremendous amount of research being directed towards a thin film alternative to traditional crystalline cells. Thin films cells are quite attractive due to the fact that many of the proposed fabrication methods are relatively inexpensive and lend themselves well to mass production. ${ }^{2}$ Inexpensive, lightweight inorganic materials such as amorphous $\mathrm{Si}, \mathrm{CuInSe}_{2}$ and $\mathrm{CdTe}$ are currently being explored for space-based energy conversion. ${ }^{3-5}$ These cells can be extremely lightweight and flexible, especially if produced on polymeric substrates.

Recently thin film polymeric cells that incorporate inorganic components such as $\mathrm{CdSe}$ or $\mathrm{CuInS}_{2}$ quantum dots have garnered much attention. ${ }^{6,7}$ Many believe it is these materials that will hold the key to inexpensive, easily deployed, large area, high mass-specific power arrays. This is due in part to the possibility of roll-to-roll processing using low-cost spray chemical deposition or direct-write approaches to producing thin film solar cells on inexpensive lightweight substrates with these materials., ${ }^{2,4}$

Alternatively, next generation thin-film technologies may well involve a revolutionary change in materials to organic-based devices. The high-volume, low-cost manufacturability of organic cells will allow for square miles of solar cell production at an estimated one-tenth the cost of conventional inorganic materials. Plastic solar cells take a minimum of storage space and can be inflated or unrolled for deployment. In comparison to current commercial inorganic photovoltaic materials, polymeric photovoltaic materials have the advantages of versatile fabrication schemes and low cost on large-scale production, therefore exhibit potential for future large-scale solar industry. For space and any portable applications, the lightweight and flexibility of polymers are key advantages.

These hybrid organic/inorganic material technologies offer the possibility of even lower-cost and higher powerto-weight ratios that may be mission enabling for Space Solar Power, Solar Electric Propulsion, or numerous military, off-grid civilian and commercial applications. NASA Glenn Research Center (GRC) currently supports a small in-house and extramural program exploring hybrid photovoltaic device technologies. What follows is a survey of enabling technologies for ultra-lightweight, inexpensive stowable solar energy conversion systems. However, to be useful for space exploration, any device or array which is developed must not only meet weight and AM0 efficiency goals, but also must be durable enough to survive relevant launch and space environments.

\section{Preparation of New Poly(isothianaphthene) (PITN) Materials and Devices}

\section{A. Background: Thin-Film Polymer Materials for Photovoltaics}

The pace of research focusing on organic photovoltaics (OPVs) has increased significantly over the past few years as power conversion efficiencies (PCE) approaching 5\% under AM1.5 illumination have been achieved. ${ }^{9}$ Although this is far less than what has been observed for inorganic solar cells, nearly $40 \%$ PCE for a multijunction structure under concentrated light, ${ }^{10}$ organic solar cells (OSCs) could provide cost-effective, light-weight, flexible photovoltaic power for consumer applications in the near future. Among different types of OSCs, polymeric solar cells are a focus of research because such a device can be easily manufactured via low-cost methods like solution casting, spin-coating, and screen-printing. Remarkable improvement in quantum efficiency has proved the efficacy of solution processing, for example. ${ }^{11}$ There are still a number challenges ahead, a good benchmark for OPV is a PCE of $10 \%$ to compete with other technologies because of several inherent polymer performance issues.

One route to improving cell performance is increasing the diffusion length of injected carriers; ordered bulk heterojunction solar cells (OBHSCs) were explored by several research groups. ${ }^{12}$ In general, an OBHSC architecture has an electron-accepting inorganic/organic material and electron-donating polymer inter-penetrating in a highly ordered fashion. For example, nano-pores of electron-accepting material can be infiltrated by electron-donating polymer. ${ }^{13}$ The aspect ratio between film thickness and the pore size often reaches over 10 considering that the optimum scale of the pores should be comparable to the diffusion length of the excitons (order of $10 \mathrm{~nm}$ ) generated by photons in typical conjugated polymers.

It is a great challenge to prepare pure samples of most conjugated conducting polymers in desired shapes and dimensions particularly as thin films because they are mostly insoluble and infusible. A typical fabrication begins by synthesizing soluble derivatives of the desired polymer, dissolving it in an appropriate solvent, and preparing polymer films via solution-based processes: simple solution casting, spin coating, or screen printing. This methodology is typically employed to fabricate optoelectronic devices including organic light emitting diodes and photovoltaic devices. ${ }^{14}$ There are a number of critical limitations for these solution-based polymer thin-film deposition methods: (i) contamination is always possible from catalysts used for polymer synthesis and solvent to make solution, which requires cumbersome solvent purification steps; (ii) solubility of the derivatives typically 
reaches only about $2 \mathrm{wt} \%$, which could leave undesirable precipitates in the films, limiting the thickness of films during processing; (iii) the derivative form of the polymers are more prone to photo-degradation because photooxidation can be easily initiated at the branch molecules added to increase the solubility; (iv) the microstructure of the polymer is generally poor because the film formation is always proceeded by the evaporation of the solvent; and (v) it is difficult to achieve conformal coating of a trench and nano-structures with a high aspect ratio.

There has been some effort to develop thin-film polymerization processes, but for optoelectronic materials there has been limited success. ${ }^{15}$ In particular, solventless, gas-phase thin-film formation by polymerization is almost limited to plasma-enhanced chemical vapor deposition (PE-CVD), ${ }^{11}$ which requires the understanding of relatively complicated plasma chemistry for organic polymer materials. In addition, there is always concern about plasma damage during the process. Another clean, solventless, and cost-effective polymer deposition method is simple thermal CVD polymerization (CVDP). In this process, thiophene-derivative conjugated polymers with a modest bandgap $(<1.8 \mathrm{eV})$ can be synthesized by CVDP for photovoltaic application. Most well known conjugated polymers for solar cells typically have a band-gap over $1.8 \mathrm{eV}$, which is too high for optimal photovoltaic devices $(\sim 1.5 \mathrm{eV})$; there is great need for a lower bandgap conjugated polymer. Only $30 \%$ of sunlight can be absorbed by a typical $200 \mathrm{~nm}$ thick polymer film with a bandgap of $2 \mathrm{eV}$. ${ }^{9}$ Although a number of surveys of lower bandgap conjugated polymers can be found, ${ }^{16,17}$ none of these material technologies employ CVDP processing. Consequently, there is almost no information available on basic synthetic chemistry for potential low bandgap conjugated polymer precursor materials to be processed via CVDP.

\section{B. Synthesis and Characterization of Poly(isothianaphthene-3,6-diyl) (PITN(3,6))}

Research at University of Texas at Arlington (UTA) has focused on the fabrication and use of poly(isothianaphthene3,6-diyl) (PITN(3,6)) in solar cells. The terminology of 3,6-diyl designates that the polymerization occurs through the phenyl ring and not the sulfur-containing heterocyclic or thiophene ring. The three-step preparation process is outlined in scheme 1 for both CVDP and a solution, synthetic method. Trimethylsilylacetylene $(0.8 \mathrm{ml}, 8.4 \mathrm{mmol})$, copper(I) iodide $(0.11 \mathrm{~g}, 0.5 \mathrm{mmol})$, triphenylphosphine $(0.12 \mathrm{~g}, 0.5 \mathrm{mmol})$, and $10 \mathrm{ml}$ of purified triethylamine were added to a stirred solution of 3,4-dibromothiophene (1.0 g, $4.2 \mathrm{mmol})$ in $20 \mathrm{ml}$ purified toluene. The solution was slowly heated in an oilbath at $60{ }^{\circ} \mathrm{C}$ under argon atmosphere. Dichlorobis(triphenylphosphine)palladium(II) $(0.059 \mathrm{~g}, 0.084 \mathrm{mmol})$ was added to reaction mixture and was heated at $80^{\circ} \mathrm{C}$ for $14 \mathrm{hr}$. After cooling to room temperature, the mixture was taken up in hexanes and filtered. The filtrate was evaporated; the residue was purified by flash column chromatography on silica gel.

A solution of 3,4-bis(2'-trimethylsilylethynyl)thiophene $(0.38 \mathrm{~g}, 1.4 \mathrm{mmol})$ in $30 \mathrm{ml}$ of methanol was stirred for 30 minutes; $\mathrm{KOH}(0.167 \mathrm{~g}, 3.0 \mathrm{mmol})$ was added and stirred for $1 \mathrm{hr}$. The solution was poured into water and extracted with $\mathrm{CH}_{2} \mathrm{Cl}_{2}$. The organic layer was dried over anhydrous magnesium sulfate, and the solvent was removed by rotary evaporation. The crude product was purified by flash column chromatography on silica gel (hexanes as eluent). For CVDP, the monomer, purified 3,4-diethynylthiophene $(30 \sim 200 \mathrm{mg}$ ), was placed in a conventional tungsten evaporation boat and vaporized at $60{ }^{\circ} \mathrm{C}$ in a steady stream $(40 \mathrm{SCCM})$ of argon at a pressure of 0.01 torr. The vaporized monomer molecules were allowed to pass through the pyrolysis (activation) zone preheated to $650{ }^{\circ} \mathrm{C}$. Polymerization occurred spontaneously when the activated monomers reached the substrate and thin-film polymer formed at room temperature.

For comparison, the UTA group also prepared PITN $(3,6)$ by Bergmann cyclization, a classical chemical ringclosing reaction, in toluene at $170{ }^{\circ} \mathrm{C}$. Polymers synthesized in solution contained terminal alkynyl groups and fivemembered rings. Very weak peaks at 3298 and $2104 \mathrm{~cm}^{-1}$ indicated that there are terminal alkynyl groups in the polymer backbone. Interestingly, polymers prepared by CVDP, used for fabricating devices, had a much cleaner Fourier transform infrared (FTIR) spectrum, without the signature of these peaks (fig. 1). A preliminary set of FTIR spectral assignments is presented in table I. Unlike conventional poly(isothiophene-2,7-diyl) PITN(2,7), where polymerization occurs through the thiophene ring, the newly synthesized polymer displayed different intensities of spectral features, ${ }^{18,19}$ with similar stretching frequencies indirectly suggesting the polymerization occurred through phenyl rings. Correlation of reaction mechanism to variation of chemical structure between polymers and more definitive analysis of FTIR spectra is the subject of on-going studies.

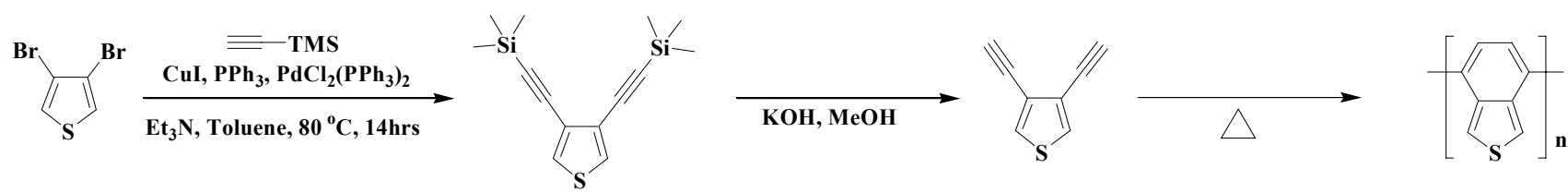

Scheme 1.-Synthetic route to monomer and PITN $(3,6)$ by both routes (step 3 ). 


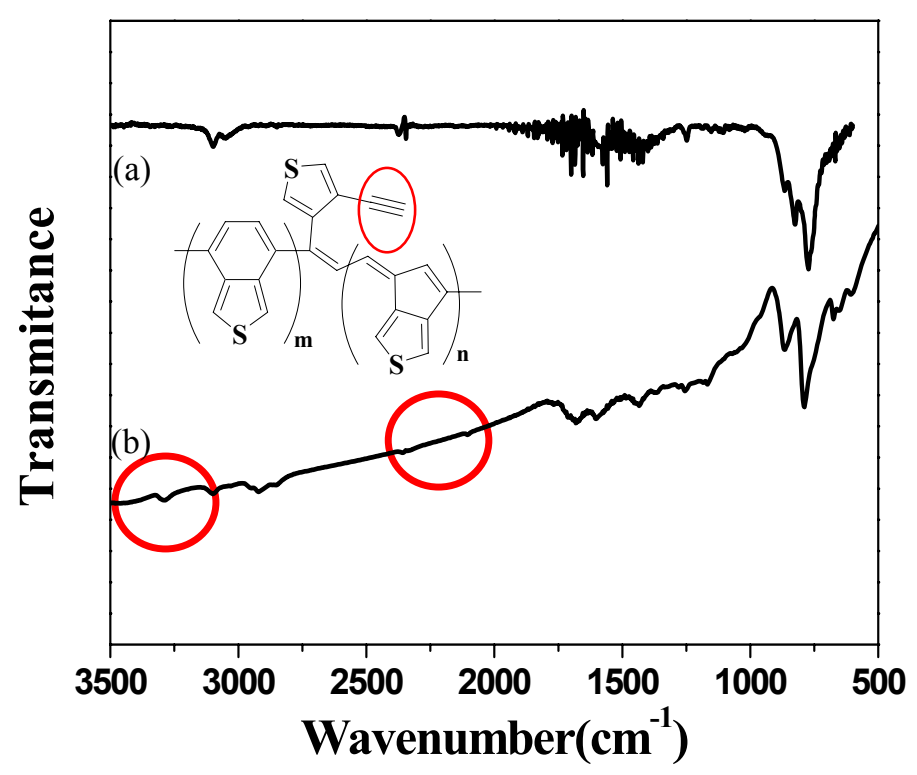

Figure 1.-FTIR spectra of PITN prepared by (a) CVDP and (b) Bergmann cyclization. Absorption bands circled in red are assigned to terminal alkynyl groups.

TABLE I.-FTIR SPEAKS OF PITN $(3,6)$

\begin{tabular}{|c|c|}
\hline Peaks $\left(\mathrm{cm}^{-1}\right)$ & Vibration mode \\
\hline 3298 & $\mathrm{C}_{\mathrm{sp}}-\mathrm{H}$ stretch \\
\hline 3060 & $\mathrm{C}_{\mathrm{sp}}{ }^{2}$-H stretch \\
\hline 2104 & $\mathrm{C} \equiv \mathrm{C}$ stretch \\
\hline 1535,1450 & $\mathrm{C}=\mathrm{C}$ ring stretch \\
\hline 1320 & $\mathrm{C}-\mathrm{S}$ stretch \\
\hline 1120 & Phenyl ring C-H stretch (in-plane) \\
\hline 840 & Phenyl ring C-H stretch (out-plane) \\
\hline 740 & Thiophene ring C-H bend \\
\hline
\end{tabular}

\section{Fabrication of Poly(isothianaphthene-3,6-diyl) (PITN(3,6)) Films and Solar Cells}

Figure 2 shows the solid-state UV-VIS absorption spectrum and cyclic voltammogram of $\operatorname{PITN}(3,6)$ films. Optical and electrochemical properties of PITN are summarized in table II. The absorption maximum of the UV-VIS spectrum is at $540 \mathrm{~nm}$; the shoulder peak at $638 \mathrm{~nm}$ is due to high molecular weight fractions. The optical bandgap of PITN $(3,6)$ prepared by CVDP is $\sim 1.8 \mathrm{eV}$, this is comparable to the bandgap of poly(3-hexylthiophene) (P3HT), commonly used for solar cells. ${ }^{20}$ Both theoretical and experimental research showed that the smaller bandgap of $\operatorname{PITN}(2,7)(1.1 \mathrm{eV})$ is caused by the intrinsic structure of its polymer backbone through thiophene rings which tends to stabilize the electronic quinoid state. ${ }^{20,21}$ A similar effect is expected for $\operatorname{PITN}(3,6)$ as the repeat units are linked through the phenyl ring; although the bandgap of $\operatorname{PITN}(3,6)$ is larger than that of $\operatorname{PITN}(2,7)$.

TABLE II.-OPTICAL AND ELECTROCHEMICAL PROPERTIES OF PITN $(3,6)$
\begin{tabular}{|c|c|c|c|c|}
\hline $\begin{array}{c}\lambda_{\max }^{\mathrm{abs}} \\
(\mathrm{nm})\end{array}$ & $\begin{array}{c}\mathrm{E}_{\mathrm{g}} \\
(\mathrm{eV})\end{array}$ & $\begin{array}{c}\mathrm{E}_{\text {onset }} \\
(\mathrm{V})\end{array}$ & $\begin{array}{c}\text { HOMO } \\
(\mathrm{eV})\end{array}$ & $\begin{array}{c}\text { LUMO } \\
(\mathrm{eV})\end{array}$ \\
\hline 540 & 1.8 & 0.6 & 5.0 & 3.2 \\
\hline
\end{tabular}


(a)

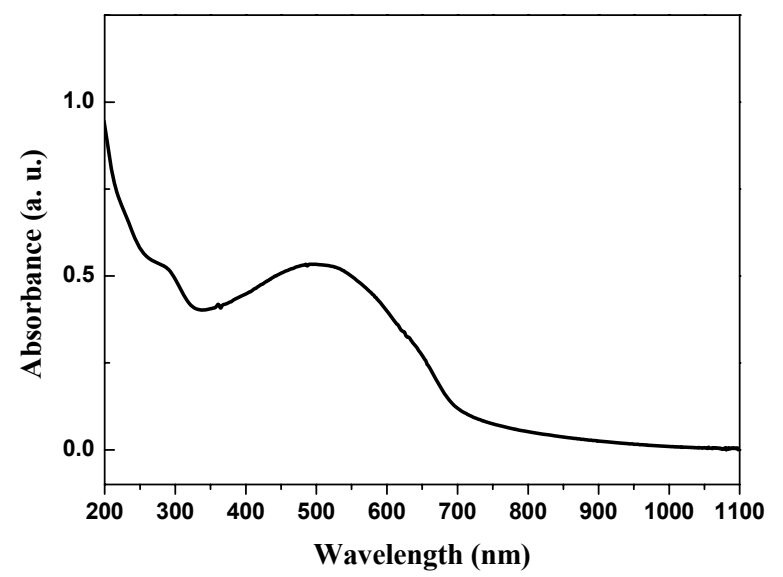

(b)

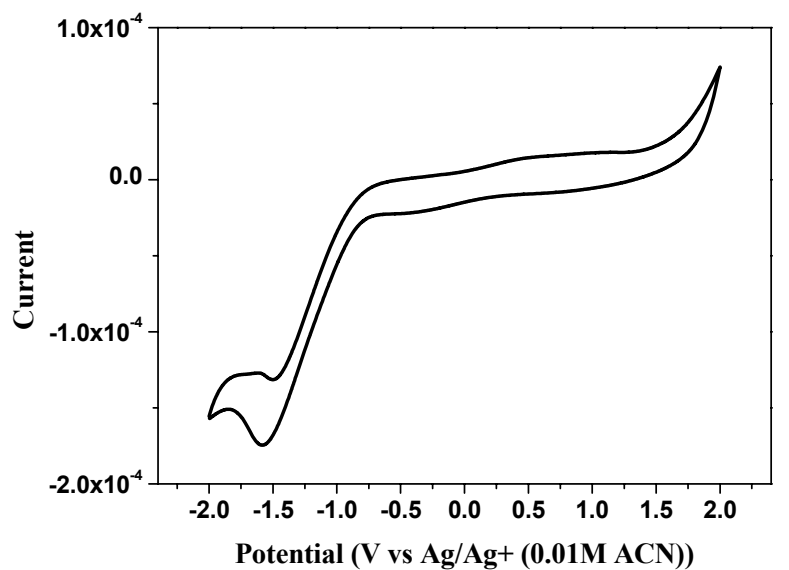

Figure 2.-Solid-state characterization of PITN(3,6): (a) UV-VIS absorption spectrum and (b) cyclic voltammetry.

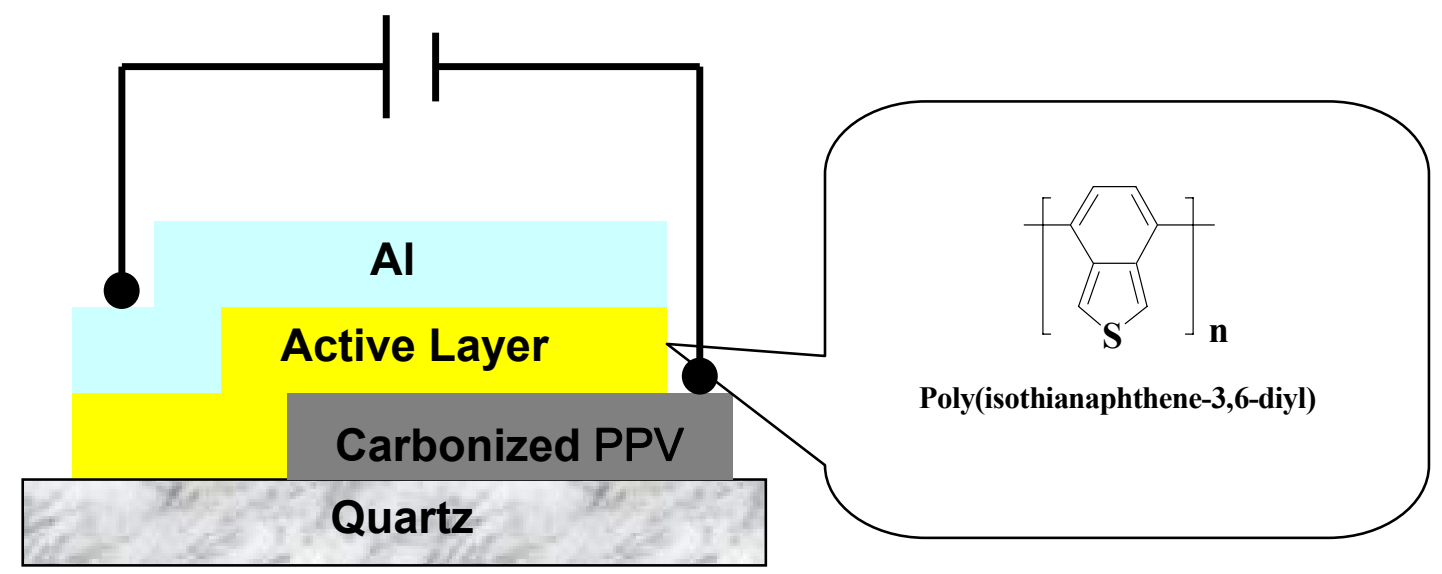

Figure 3.-Photovoltaic device architecture and chemical structure of PITN $(3,6)$, the active compound.

A schematic of a layered heterojunction cell with CPPV (carbonized polyphenylenevinylene)/PITN $(3,6) / \mathrm{Al}$ where carbonized PPV film is used as a junction counterpart of $\operatorname{PITN}(3,6)$, is shown in figure 3. First, PPV film $(300 \mathrm{~nm})$ was prepared by CVDP on a quartz substrate, which is necessary for the subsequent carbonization process at high temperature. A PPV film was carbonized at $1000{ }^{\circ} \mathrm{C}$ for $1 \mathrm{hr}$ under flowing argon to obtain a nanocrystalline graphitic layer. A $40 \mathrm{~nm}$ thick PITN $(3,6)$ layer was deposited from $50 \mathrm{mg}$ of monomer on top of CPPV. Finally, an Al layer $(30 \mathrm{~nm})$ was deposited by thermal evaporation.

The thin carbonized PPV layer produced in this study followed the procedure described in a report published previously. ${ }^{22}$ The degree of carbonization was studied by Raman spectroscopy. The spectrum (not shown) indicated two distinct peaks at 1350 and $1590 \mathrm{~cm}^{-1}$. The former is characteristic of a defective graphite structure and called Dmode, whereas the latter is from well-ordered graphitic structure and called G-mode. From the relative intensity and area of the peaks, we estimated the average graphitic diameter $\left(L_{a}\right)$ or in-plane correlation length. The $L_{a}$ value reached $2.0 \mathrm{~nm}$, which indicates that about 8 graphitic rings are in one cluster.

The solar cell was characterized with a homemade solar simulator under AM0 conditions. A standard crystalline Si solar cell was used for the calibration of the light intensity. Initial attempts to grow solar cells yielded a typical open circuit voltage $\left(V_{o c}\right)$ of $300 \mathrm{mV}$. At this writing, short circuit currents $\left(\mathrm{I}_{\mathrm{sc}}\right)$ are quite low. The low current can be partially ascribed to a very thin absorber layer and unoptimized electrode configuration. Work is on-going to improve the performance of solar cells.

In summary, new thiophene-derivative conjugated polymer thin films with the potential for a variable bandgap have been successfully deposited by CVDP for photovoltaic applications. Thus far, the UTA group has synthesized PITN $(3,6)$ with the monomer precursor, 3,4-diethynylithiophene via a conventional chemical method and CVDP. Structural characterization confirmed the chemical vapor reaction was cleaner than the solution synthetic process 
and the band-gap of about $1.8 \mathrm{eV}$ was measured by optical absorbance and cyclic voltammetry. A bi-layer heterojunction between $100 \mathrm{~nm}$ thick graphite and $30 \mathrm{~nm}$ thick PITN(3,6) was fabricated; an open circuit voltage of about $300 \mathrm{mV}$ was measured under simulated AM0 conditions. CVDP could be complementary to typical solution process enabling any multijunction polymer thin-film devices. Work is proceeding to utilize the PITN molecular template and CVDP process to tailor the electronic properties polymer films to enable improved performance.

\section{Performance Enhancement via Bridged Donor/Acceptor Block Copolymers}

It has been observed that photo-induced electron transfer (electron-hole charge separation) at the interface of an organic donor (p-type) and an organic acceptor (n-type) through either space or covalent bonds is several orders of magnitude faster than the radiative or non radiative decay of the photo generated exciton, ${ }^{23}$ and also orders of magnitude faster than charge recombination. ${ }^{24}$ This offers an opportunity for developing high efficiency organic opto-electronic (such as photovoltaic) devices using organic donor/acceptor binary materials systems. ${ }^{25-27}$

Such materials systems have already been demonstrated using a number of device structures, such as a donor/acceptor bilayer, ${ }^{25}$ donor/acceptor blend (also called 'bulk heterojunctions'), ${ }^{26}$ or D-A diblock copolymer (one being a non-conjugated block). ${ }^{27}$ However, the PCE of currently reported organic/polymeric photovoltaic materials are still relatively low (typically less then 6\%) compared to inorganic crystalline photovoltaic materials (typically over 15\%). This low efficiency conversion in organics can be attributed mainly to three major losses including: 'photon loss,' 'exciton loss,' and 'carrier loss' due to improper materials frontier orbital levels and poor spatial morphologies. ${ }^{28,29}$

For instance, the relatively small and limited donor/acceptor (D/A) interface and long exciton pathway in D/A bilayer system can result in only a small fraction of the photo generated excitons being captured and separated, and this contributes to 'exciton loss' ${ }^{28}$ The poor bi-continuous morphology in D/A blend or the non-conjugated polymer block in D-A diblock copolymer will result in very poor carrier transport away from the separating field towards an electrode, and thus lead to severe 'carrier loss' ${ }^{29}$ To address the carrier loss issue, conjugated block copolymers have been suggested to increase the conductivity of the polymer. ${ }^{29}$ However, when a D-A diblock-copolymer was formed with both D and A being conjugated blocks, no charge-separated states were observed, possibly due to ultrafast charge recombination. Additionally, the processability of the material was also poor due to rigidity of conjugated blocks. ${ }^{30}$

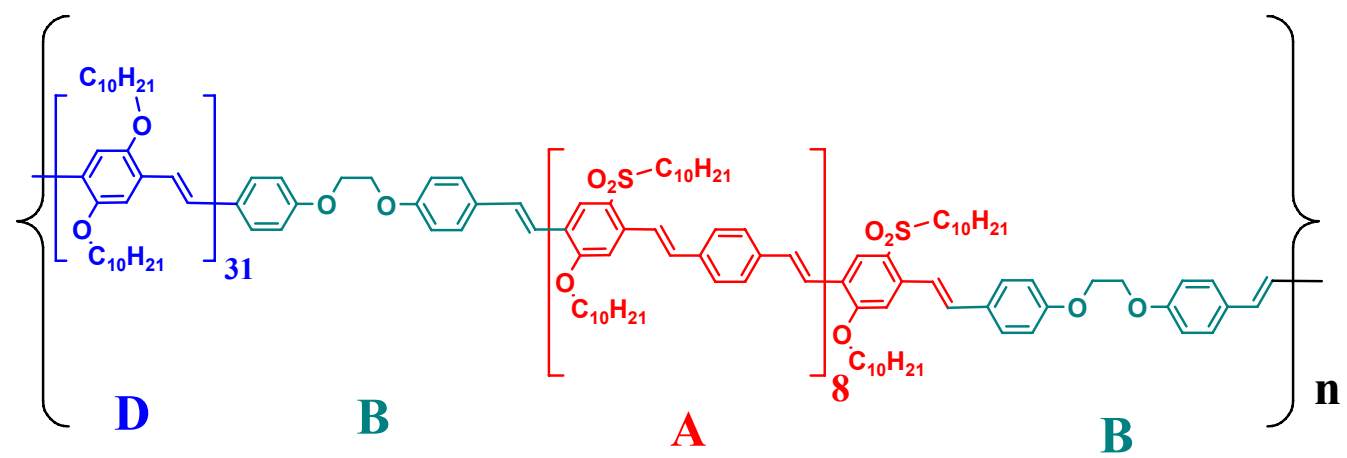

(a)

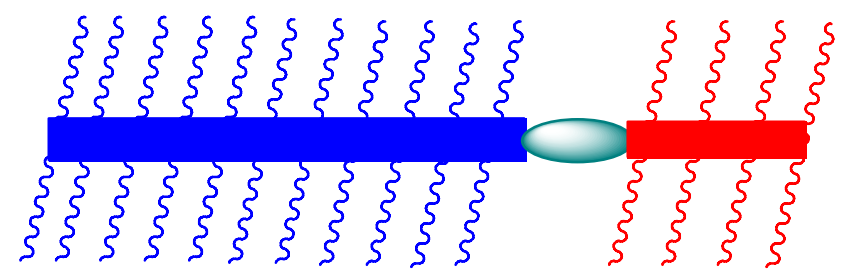

(b)

Figure 4.-Primary molecular (a) and secondary (b) structures of the synthesized-DBAB-type block copolymer. 
In work focused at Norfolk State University (NSU), a -DBAB- type of block copolymer (fig. 4) has been designed, synthesized and characterized; ${ }^{28,31,32} \mathrm{D}$ is an donor alkyloxy-derivatized poly-p-phenylenevinylene (RO-PPV), $\mathrm{A}$ is an acceptor alkyloxy-sulfone derivatized poly-p-phenylenevinylene (SF-PPV), and B is a non-conjugated and flexible bridge chain unit. In this system, the flexible and high bandgap bridge unit (B) not only retards electron-hole recombination between the donor and acceptor block, it is also enables the rigid donor and acceptor blocks to self assemble to form desired 'secondary' and 'tertiary' structures. ${ }^{28}$ Previous studies have already observed that such kind of advanced morphological structures were crucial for enhancing charge carrier mobility in organic materials. ${ }^{33}$

In comparison to a simple D/A blend system having the same energy levels, block (-DBAB-) copolymers exhibited much better photoluminescence (PL) quenching, ${ }^{34}$ and better photovoltaic properties (fig. $5, J_{s c}=0.058 \mathrm{~mA} / \mathrm{cm}^{2}$ versus $0.017 \mathrm{~mA} / \mathrm{cm}^{2}$ and $V_{o c}=1.10 \mathrm{~V}$ versus $0.14 \mathrm{~V}$ ) under identical conditions in a not yet optimized device. ${ }^{35}$

Morphological studies revealed molecular self-assembly ordered pattern in the block copolymer thin film under simple thermal annealing (figs. 6 and 7). Since the charge carrier injection density is the same, the enhanced carrier mobility is therefore attributed mainly to a smoother carrier transport pathway, which is directly correlated to the block copolymer thin film phase-separated and bi-continuous morphology. Thus, the -DBAB- type of block copolymer is very promising for the development of high efficiency plastic electrical and optoelectronic devices where carrier mobility is critical. Work continues to optimize polymer cells exploiting this materials system at NSU.

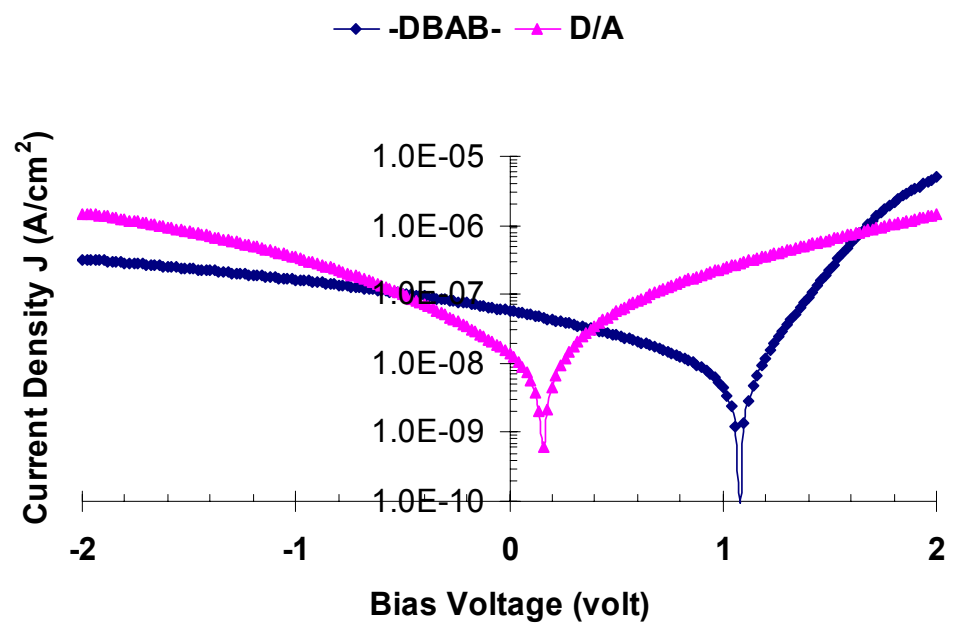

Figure 5.—J-V curves of donor/acceptor blend film (triangle) and -DBAB- block copolymer film (diamond).

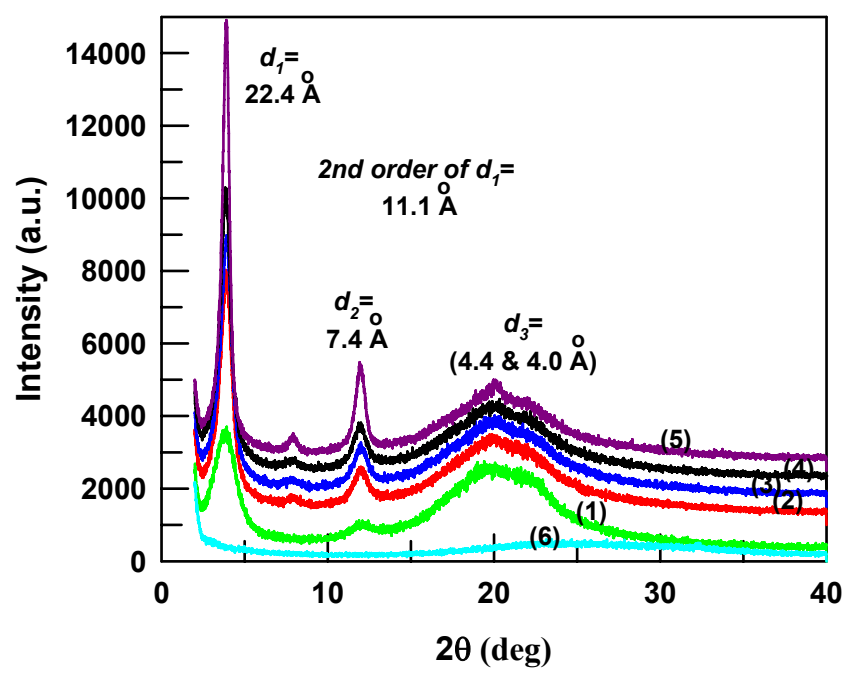

Figure 6.-XRD powder patterns of -DBAB- block copolymer film before annealing (1) and after annealing at $110^{\circ} \mathrm{C}$ for (2) $1 \mathrm{hr}$, (3) $3 \mathrm{hr}$, and (4) $5 \mathrm{hr}$ and (5) after annealing at $140{ }^{\circ} \mathrm{C}$ for $5 \mathrm{hr}$ and glass substrate (6) before annealing. 


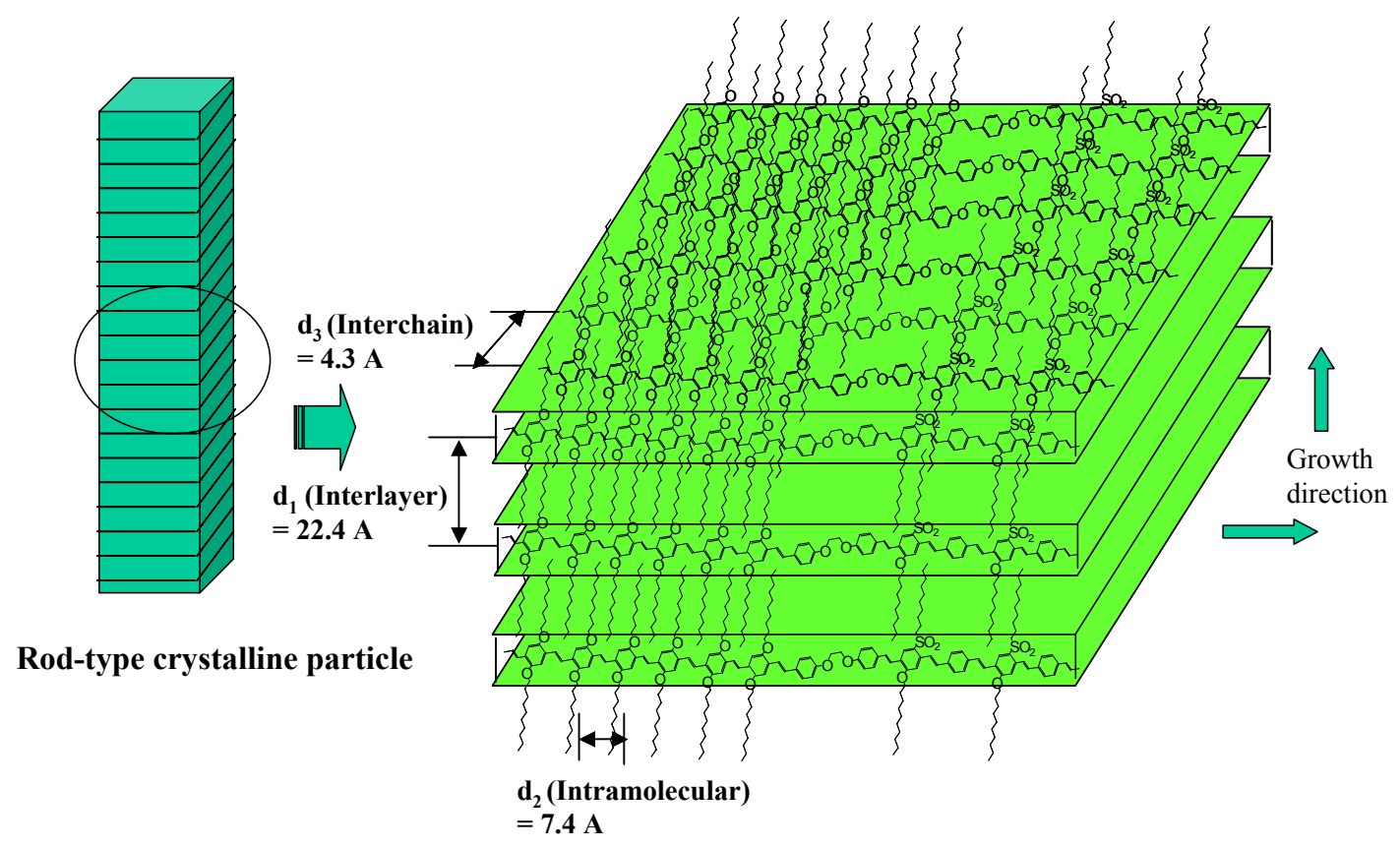

Figure 7.-Stacking scheme of -DBAB- block copolymer film after annealing at $140^{\circ} \mathrm{C}$ for $5 \mathrm{hr}$.

\section{Multijunction Polymer Solar Cells}

A particularly successful approach to achieving high photovoltaic efficiency is the multijunction solar cell. A cell comprising stacked heterojunctions of Ge, GaAs and GaInP (in order of increasing bandgap) has been demonstrated with a record efficiency of $40.7 \%$ and is sold commercially by Spectrolab with an AM0 specification of $29 \%$. The open circuit voltage $\left(V_{o c}\right)$ of such a cell is the serial addition of the constituents while the current is usually somewhat less than a single cell made from the most efficient absorber component. Thus, all of the power gains of this type of cell derive from $V_{o c}$ while resistive losses are minimized. A collaborative team between EIC Laboratories and the University of Florida (UF) is investigating the application of the multijunction approach to organic polymer "bulk heterojunction" solar cells. A schematic of a three-junction device is shown in figure 8, highlighting the material requirements.

The structure is based on an integrated stack of three donor-acceptor type cells absorbing the blue, green and red regions of the solar spectrum, respectively. The device harvests blue, green and red solar photons separately, maximizing the $V_{o c}$ obtained from each wavelength region. The donor is shown as the primary absorber and the same acceptor (e.g., a fullerene derivative like 1-(3-methoxycarbonyl)propyl-1-phenyl[6,6] $\left.\mathrm{C}_{61}, \mathrm{PCBM}\right)$ is used for all three component layers. The maximum $V_{o c}$ of each cell is the energy difference between the donor HOMO and the acceptor LUMO. ${ }^{16} \mathrm{We}$ therefore require donors of large (blue), medium (green) and low (red) bandgap for this type of device, with the further requirement that the reduction in bandgap be due to an increase in energy of the donor HOMO level while the acceptor LUMO remains relatively constant. The device harvests blue, green and red solar photons separately, maximizing the $V_{o c}$ obtained from each wavelength region. The output is like three batteries in series. The cells are connected internally by thin transparent metal charge recombination layers, $\mathrm{M}_{\mathrm{r}}$. The top (transparent) and bottom current collection contacts, $\mathrm{M}_{1}$ and $\mathrm{M}_{2}$, optimally have work functions which match the energies of the HOMO of the blue absorbing donor moiety and the LUMO of the acceptor (here PCBM), respectively. The EIC/UF team is enlisting the synthetic versatility of organic materials as an approach to "bandgap engineering" of the constituent donor polymers.

The University of Florida is exploring conjugated polymers with alternating electron rich and electron poor moieties as an approach to bandgap engineering. They have synthesized and characterized conjugated polymers comprising different electron rich groups, such as a bis-(ethylene dioxythiophene), alternating with the electron poor group cyanovinylene $(\mathrm{CNV}) .{ }^{36}$ They found that the HOMO energies of these polymers are mostly determined by the choice of electron rich group, while the LUMO is determined by the $\mathrm{CNV}$, and is relatively constant $(\sim 3.5$ to $3.7 \mathrm{eV}$ versus vacuum). The energy levels of three of these donor polymers, which would be candidates for the blue, green and red absorbers in figure 8, are shown in figure 9. Also shown is the LUMO energy level for PCBM. From figure 9 we see that the blue, green and red theoretical $V_{o c}$ values are $1.75,1.45$, and $1.15 \mathrm{~V}$. Photovoltaic cells made from these polymers have undergone very limited development; ${ }^{36}$ they have not been optimized for uniformity and charge carrier mobility of 
the polymer layer, so $V_{o c}$ 's have been far less than the theoretical values. The dependence of $V_{o c}$ on the donor HOMO acceptor LUMO energy difference has been demonstrated in other bulk heterojunction devices.

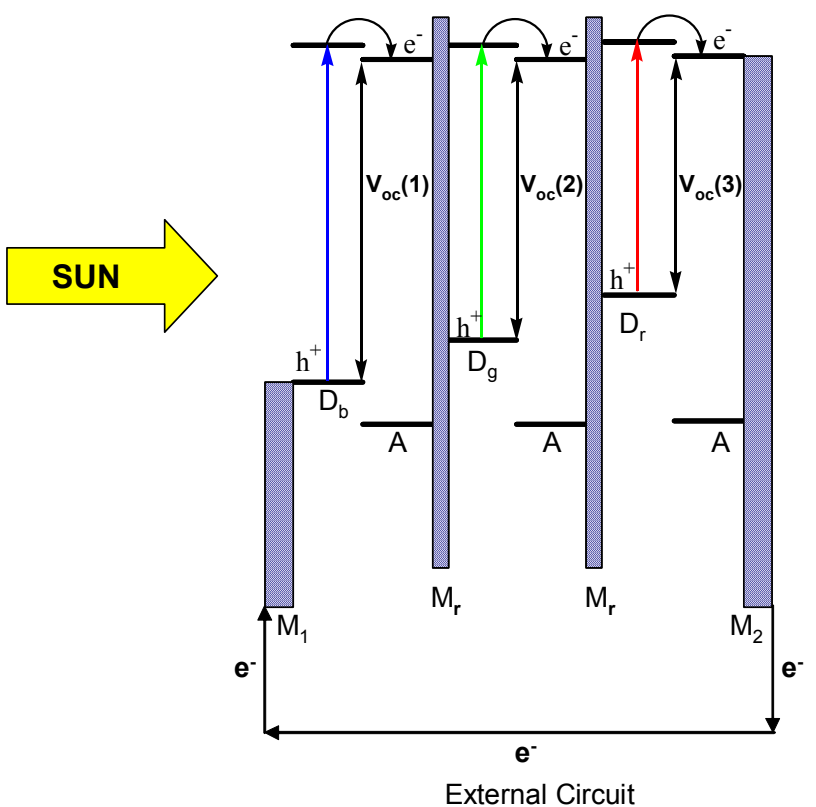

Figure 8.-Schematic diagram of a three-layer "bulk heterojunction" photovoltaic device. Each layer comprises a solid solution of a highly absorbing blue, green or red donor $\left(D_{b}, D_{g}\right.$, and $\left.D_{r}\right)$ and an acceptor, $A$.

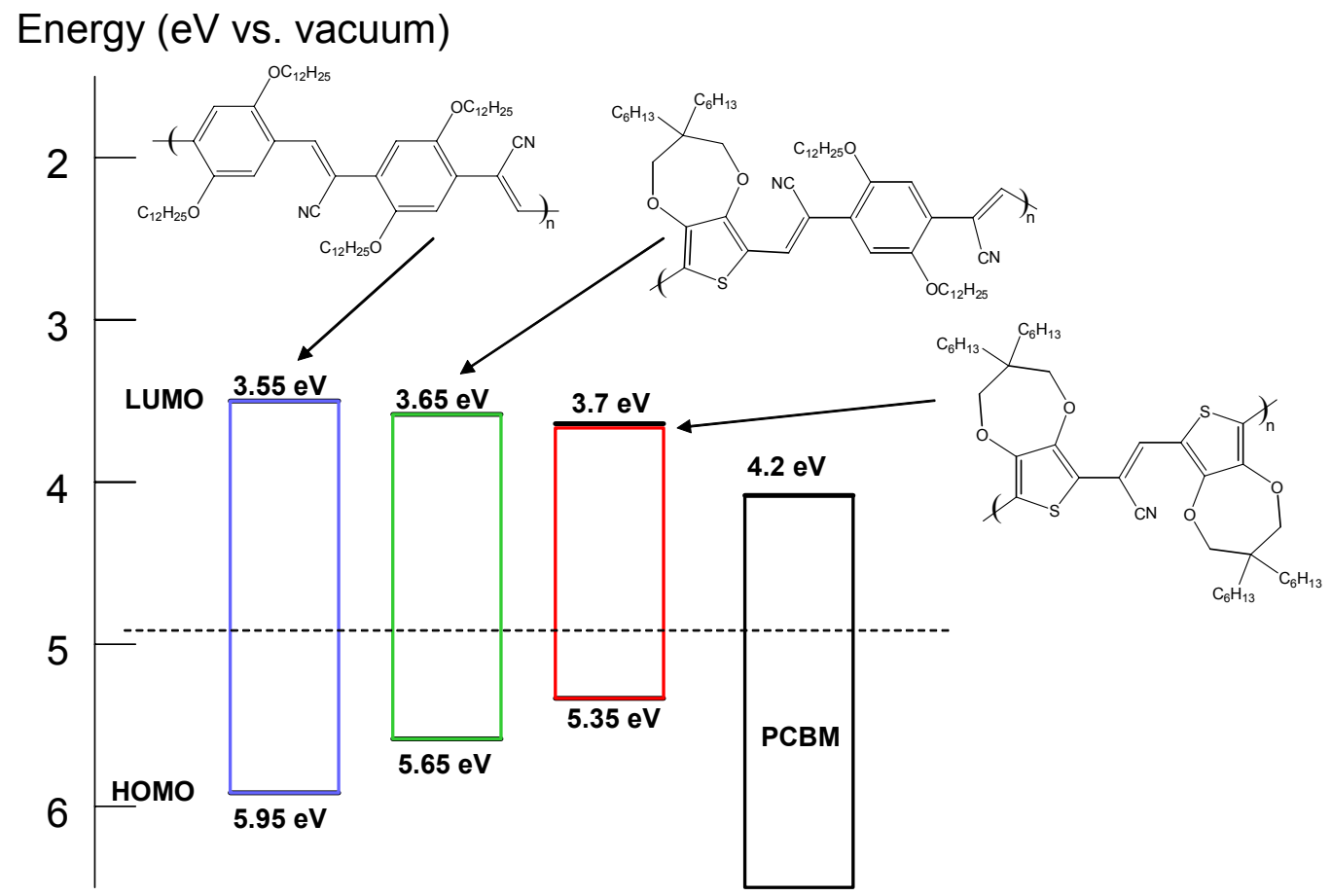

Figure 9.-Experimentally determined HOMO and LUMO energies of blue, green and red cyanovinylene-based polymer candidates for a multijunction photovoltaic device (from ref. 36). Also shown is the LUMO of the acceptor PCBM. The polymers are oxygen stable since their HOMO levels are below the oxygen reduction potential (dotted line). 
There are additional challenges to be overcome in making a multijunction organic polymer PV device. As indicated in figure 8 , each cell must be separated by a transparent tunnel junction. The individual cells and metallizations need to be deposited sequentially using a process that does not disturb the underlying layers. Hence, solution processing must be carefully designed with compatible solvents, for example. ${ }^{29}$

\section{Processing of Polymer and Inorganic Materials for Ultralightweight Hybrid Solar Cells}

Several recent publications describe efforts at NASA GRC to develop enabling technologies for ultra-lightweight inorganic and hybrid solar cells. ${ }^{7,8,37-40}$ In the next two sections of this publication, we describe efforts to process polymer and inorganic materials to produce solar cells for the purpose of manufacturing solar arrays. Developing processes for use of lightweight polymer substrates mandates an understanding of the impact of thermal degradation on polymers under relevant conditions. An initial thermal analysis study of several potential substrate materials is described. Developing an approach to process active polymer materials to deposit onto polymer substrates and subsequent device optimization is also required. Moving beyond research to develop manufacturable processes is the goal of such an effort. Preliminary efforts to establish a broad in-house capability to produce practical solar arrays are detailed. Finally, we briefly review our efforts in the production of I-III-VI 2 quantum dots (QDs). The inclusion of both QDs and/or carbon nanotubes (CNTs) could increase the efficiency of primarily organic devices to the point where the resulting hybrid solar cells become a practical option for space power generation.

\section{A. Thermal Analysis of Substrate Materials}

Use of flexible solar cells will be mission enabling for several proposed NASA space programs, which allows for efficient storage in launch vehicles for later controlled deployment in space. Similarly, for terrestrial applications, thin film photovoltaics are highly appealing due to their flexible lightweight construction, permitting them to be "molded" onto non-rigid, or uniform structures for recreational or innovative power systems. The NASA/OAI group has undertaken a thermal materials study of potential metallized substrates from Techni-Met, Inc. to determine their viability for use in a low temperature solar cell fabrication process such as spray assisted CVD. ${ }^{8,38,40}$ Thermal decomposition data were collected via thermogravimetric analysis (TGA) of five thin film polymer coupons (polyimide (Upilex) ${ }^{*}$ and polyethylene terephthalate (PET)), see table III.

TABLE III.-THERMOGRAVIMETRIC ANALYSIS (TGA) OF FIVE METALLIZED THIN FILM POLYMERS

\begin{tabular}{|c|c|c|c|c|c|c|c|c|c|c|}
\hline \multicolumn{4}{|c|}{$\begin{array}{l}\text { Thin film } \\
\text { polymer coupon data }\end{array}$} & \multicolumn{2}{|c|}{$\begin{array}{l}\text { First weight } \\
\text { change to } 250{ }^{\circ} \mathrm{C} \\
\text { (water loss) }\end{array}$} & \multirow{2}{*}{$\begin{array}{l}\text { Onset } \\
\text { temp. } \\
\text { decomp. } \\
\left({ }^{\circ} \mathrm{C}\right)\end{array}$} & \multicolumn{2}{|c|}{$\begin{array}{l}\text { Second weight } \\
\text { change }\end{array}$} & \multicolumn{2}{|c|}{$\begin{array}{c}\text { Residue } \\
\text { (WT\%@ }{ }^{\circ} \mathrm{C} \text { ) }\end{array}$} \\
\hline $\begin{array}{l}\text { Polymer } \\
\text { type }\end{array}$ & $\begin{array}{l}\text { Metal } \\
\text { layer }\end{array}$ & $\begin{array}{l}\text { Thickness } \\
\text { (mil) }\end{array}$ & $\begin{array}{l}\text { Resistivity } \\
\text { (ohm/sq) }\end{array}$ & $\begin{array}{c}\text { Max. rate } \\
\text { WT loss } \\
\left({ }^{\circ} \mathrm{C}\right)\end{array}$ & $\begin{array}{c}\text { WT } \\
\text { loss, } \\
\%\end{array}$ & & $\begin{array}{c}\text { Max. rate } \\
\text { WT loss } \\
\left({ }^{\circ} \mathrm{C}\right)\end{array}$ & $\begin{array}{c}\text { WT } \\
\text { loss, } \\
\%\end{array}$ & $\begin{array}{c}\text { WT, } \\
\%\end{array}$ & $\begin{array}{c}\mathrm{T} \\
\left({ }^{\circ} \mathrm{C}\right)\end{array}$ \\
\hline 1. Upilex & Mo & 1 & 0.6 & 119.7 & 1.9 & 534.5 & 614.3 & 32.4 & 65.7 & 900 \\
\hline 2. Upilex & Mo & 1 & 1.0 & 108.3 & 1.6 & 523.2 & 611.3 & 34.4 & 63.9 & 900 \\
\hline 3. Upilex & Mo & 1 & 7.5 & 122.4 & 1.8 & 525.4 & 610.8 & 35.9 & 62.1 & 900 \\
\hline 4. Upilex & $\mathrm{Pd}$ & 1 & $<5.0$ & 114.6 & 2.1 & 530.1 & 612.8 & 33.5 & 64.4 & 850 \\
\hline 5. PET & $\mathrm{Au}$ & 10 & 2.2 & 169.7 & 1.4 & 360.6 & 427.4 & 87.2 & 11.4 & 650 \\
\hline
\end{tabular}

Several runs were performed on each type of coupon until all decomposition onset temperature (Upilex samples only) data was within $\pm 5 \%$. It is important to note that the initial weight change transition from the beginning of the run (room temperature) to $250{ }^{\circ} \mathrm{C}$ is due to absorbed and adsorbed water, as reported in the data sheet furnished by Techni-Met, Inc. Therefore, in table I, the "weight change up to $250^{\circ} \mathrm{C}$ " is the weight change due to water loss. The "second weight change," which is from 400 to $900{ }^{\circ} \mathrm{C}\left(850^{\circ} \mathrm{C}\right.$ for Palladium) for the Upilex samples, and from 300 to 650 for the PET sample, is the decomposition weight change. The "decomposition onset temperature," is the temperature at which the metallized polymer coupons begin to decompose, in other words, the onset of the "second weight change." Figure 10 illustrates a typical decomposition experiment with a Mo on Upilex coupon.

\footnotetext{
${ }^{*}$ See URL for information on Upilex from the manufacturer: http://www.uniglobe-kisco.com/Upilex.htm
} 
Examination of the data shows that each metallized Upilex sample has an average water content (by weight loss) of $1.85 \%$. The presence of water may in fact be beneficial to CIS thin film device fabrication, since it is known that selective doping with oxygen can increase cell efficiencies. Alternatively the relative ease of loss of water at under $250{ }^{\circ} \mathrm{C}$ is well below the deposition temperature of the absorber layer. Furthermore the thermal profiles of the metallized samples shows that the released water vapor has no chemical effect on the sample such as oxidation, which would be observable by a gain in the sample weight.

The main thermal event for the metallized polymer samples is decomposition, which is found to occur at temperatures of greater then $500{ }^{\circ} \mathrm{C}$. The maximum rate of decomposition occurs at approx $610{ }^{\circ} \mathrm{C}$, this is ideal for our spray CVD process which is conducted at $400{ }^{\circ} \mathrm{C}$. Initial testing of the Upilex (1 mil)/Mo in the CVD reactor for depositing $\mathrm{CuInS}_{2}$ proved difficult since the polymer substrate would curl in the reactor. This problem can be resolved by using a thicker Upilex/Mo substrate, (5 to $10 \mathrm{mil})$, and/or metallizing the polymer on both sides. Further thermal and electrical testing is in progress to determine coefficient of thermal expansion, (CTE), the dielectric constant, glass transition and related properties. From these, a suitable substrate will be selected and used for deposition of device layers for fabricating thin film on polymer solar cells.

\section{B. Bulk Heterojunction Polymer/Carbon Nanotube Solar Cells}

Fabrication of bulk heterojunctions with vertically well-ordered arrays of organic semiconductors and carbon nanotubes (CNTs) is a promising route to increasing the efficiency of polymer photovoltaic cells. In such structures, essentially all excitons are formed sufficiently close to the organic-CNT interface to be dissociated by electron transfer. Thus, all charge carriers have an uninterrupted pathway to the electrodes. The polymer chains are aligned to increase their charge carrier mobility. Ordered structures are relatively easy to model; characterization of ordered cells will to lead to better design rules for making efficient photovoltaic cells. If successful, this technology will enable the development of plastic solar cells with efficiencies approaching those of thin film solar cells. Figure 11 shows a schematic of a device structure, processing equipment, and multi-wall (carbon) nanotubes (MWNT) produced using an atmosphere-assisted CVD process.
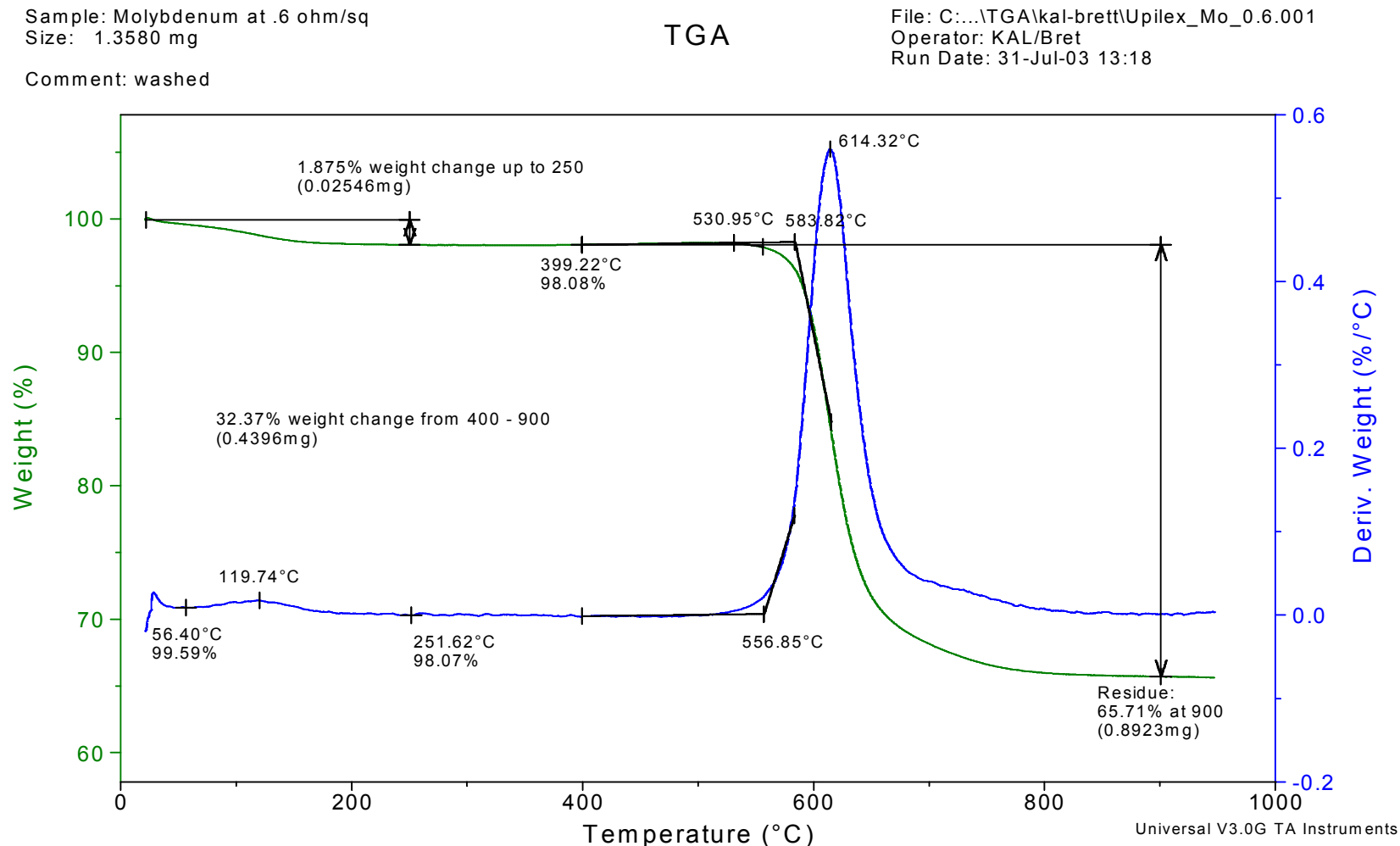

Figure 10.-Thermal decomposition profile for Upilex coupon 1 (Upilex/Mo $(0.6 \mathrm{Ohm} / \mathrm{sq})$. 


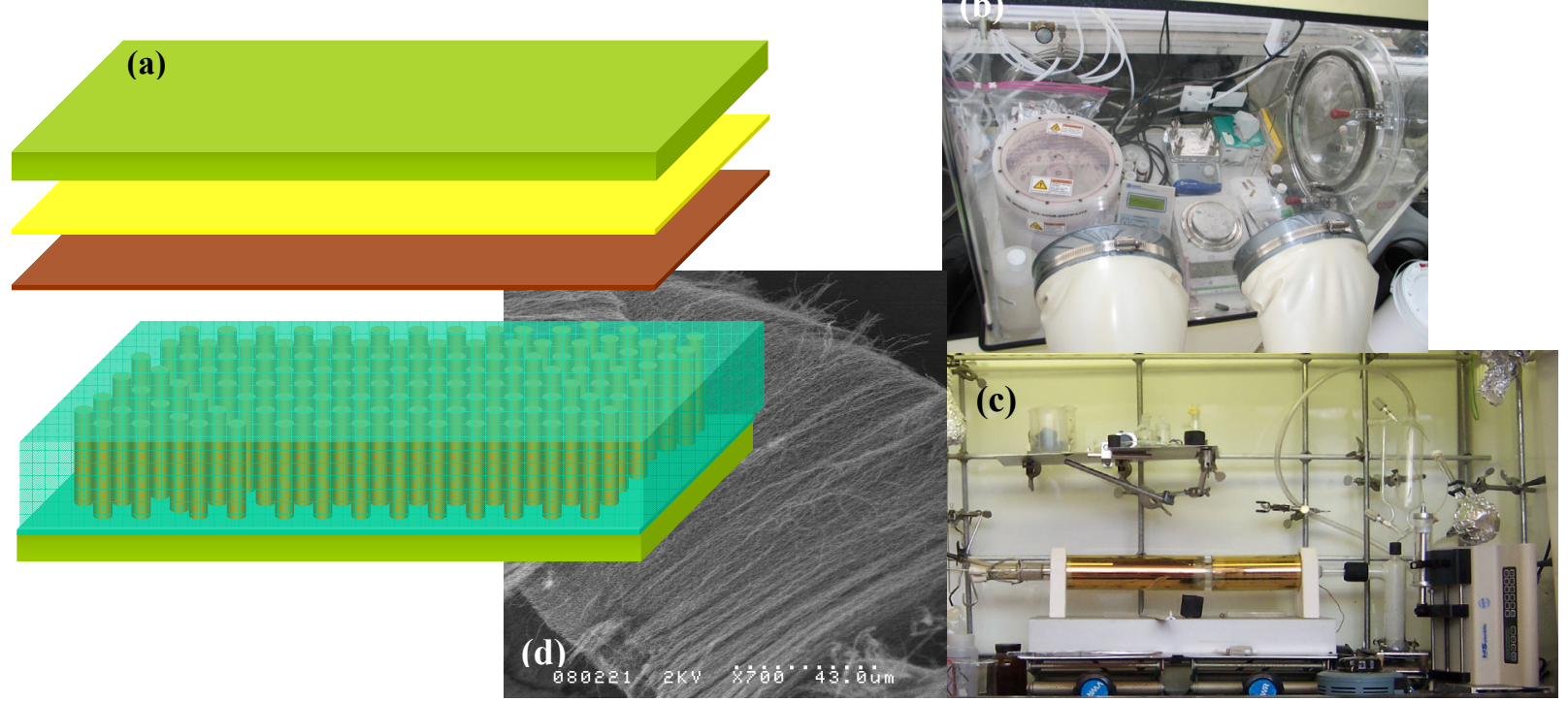

Figure 11.-Clockwise starting in upper left-hand corner: (a) schematic of polymer/CNT device, (b) spinner for processing polymer materials, (c) CVD tool for producing CNTs, and (d) SEM of MWNTs.

The ordered device structure has several advantages over typical bulk heterojunction device which has randomly dispersed electron accepting nanomaterials. First, the dimensions of both phases can be controlled to ensure that every spot in a film is within an exciton diffusion length of an interface between the two semiconductors. Second, there are no dead ends in the structure thus enabling charge carriers straight pathways to the electrodes. The carriers escape the device as quickly as possible minimizing recombination. Third, in an ordered structure it is possible to align conjugated polymer chains, which increases the mobility of their charge carriers. Ordered bulk heterojunction photovoltaic cells, such as shown in figure 11(a) can advance this technology, further achieving higher energy conversion efficiencies. There is considerable interest in testing the organic photovoltaic cells in a simulated space environment when organic photovoltaic solar cells on flexible substrates with cell efficiencies $>10 \%$ AM0 have been demonstrated. As discussed above, there is also interest in developing array technology that takes advantage of the high specific power, low stowed volume, and flexibility of such technologies.

\section{Quantum Dots for Preparing Nanocomposite Materials}

The inclusion of nanocrystalline materials in photovoltaic devices has been proposed as a means to improve the efficiency of photon conversion (quantum dot solar cell), ${ }^{41}$ enable low-cost deposition of thin-films, ${ }^{42}$ provide sites for exciton dissociation, ${ }^{6}$ and pathways for electron transport. ${ }^{43}$ With respect to their use in quantum dot solar cells and exciton dissociation, the size of the nanoparticle is an important factor in determining the optoelectronic properties of the material. When the size of a semiconductor quantum dot drops below that of the exciton Bohr radius (of the bulk material) the energy levels become quantized and the bandgap increases as the particle size decreases. In this size regime the bandgap can be "tuned" to a desired energy by adjusting the particle size.

The chalcopyrite semiconductors $\mathrm{CuInS}_{2}$ and $\mathrm{CuInSe}_{2}$ have been proposed as highly efficient thin-film photovoltaic materials. Thin-film $\mathrm{CuInS}_{2}$ cells with efficiencies of $12.5 \%$ have been successfully produced, ${ }^{44}$ while CuInSe ${ }_{2}$ cells have been recorded up to $18 \%$ efficiency. ${ }^{45}$ The bandgap of $\mathrm{CuInS}_{2}\left(\mathrm{E}_{\mathrm{g}}=1.5 \mathrm{eV}\right)$ is a good match to the AM0 solar spectrum, and CuInSe $e_{2}\left(\mathrm{E}_{\mathrm{g}}=1.1 \mathrm{eV}\right)$ is a promising low-cost electro-optical material. ${ }^{45}$

Quantum dots are also expected to be resistant to degradation from electron, proton, and alpha particle radiation, a requirement for use in space solar cells. ${ }^{46-48}$ In III-V materials, an InP p-i-n cell with quantum wells of InAsP has been shown to have greater resistance to proton irradiation than an unadulterated InP cell. ${ }^{47}$ It is expected that the same trend will be observed for I-III-VI 2 materials as well. ${ }^{48}$

Only a few reports have been published about the synthesis of the ternary materials $\mathrm{CuInS}_{2}$ and $\mathrm{CuInSe}_{2}$ with very small particle size. O'Brien and co-workers reported the synthesis of $\mathrm{CuInSe}_{2}$ nanoparticles from the chlorides and trioctylphosphine oxides (TOPO) and related compounds to form nearly spherical crystals with a diameter of 
approximately $4 \mathrm{~nm} \cdot{ }^{49}$ Czekelius et al. reported the formation of elongated nanocrystallites of $7 \mathrm{~nm} \mathrm{CuInS} \mathrm{S}_{2}$ by treatment of a $\mathrm{Cu}^{\mathrm{I}}-\mathrm{P}(\mathrm{OPh})_{3} / \mathrm{In}^{\mathrm{III}}-\mathrm{P}(\mathrm{OPh})_{3}$ mixture in acetonitrile with $(\mathrm{TMS})_{2} \mathrm{~S}^{50}$ Gurin reported the formation of nanocrystals of $\mathrm{CuInS}_{2}$ or $\mathrm{CuInSe}_{2}$ by treatment of an aqueous mixture of $\mathrm{CuCl}$ and $\mathrm{In}_{2}\left(\mathrm{SO}_{4}\right)_{3}$ with hydrogen sulfide or hydrogen selenide, respectively. ${ }^{51}$ In each case, the authors observed blue shifts of the absorption onset of the material with respect to the bulk values, indicative of size-induced quantum confinement. Qian and coworkers have reported a series of solvothermal routes to nanorods of $\mathrm{CuInS}_{2}$ and $\mathrm{CuInSe}_{2}$. ${ }^{52,53}$

In practice however, synthesis of a desired size nanoparticle is not always simple. This is especially true for the higher-order ternary and tertiary materials. If separate sources are used for the different metals and chalcogenides, often binary materials are preferentially formed as a result of different solubility of the products and reactivity of the precursors. One method to circumvent the formation of undesirable reaction products is through the use of singlesource precursors. Single-source precursors are small molecules which include all the elements required in the final material. These precursors can be designed with many properties in mind including stoichiometry, solubility, and volatility. As CuInS ${ }_{2}$ is a promising material for thin-film photovoltaics and quantum dot solar cells, our group has studied the synthesis of potential precursors to $\mathrm{CuInS}_{2}$, and the subsequent conversion of the precursors to thin-films of the bulk semiconducting materials. The molecular precursor $\left(\mathrm{PPh}_{3}\right)_{2} \mathrm{CuIn}(\mathrm{SEt})_{4}$ (fig. 12) was first described by Hirpo et al. in 1993. ${ }^{54}$ This charge-neutral molecule comprises a copper(I) ion bound by two triphenylphosphine ligands, an indium(III) ion with two terminal ethanethiolate ligands, and two bridging ethanethiolate ligands between the metal centers. This molecule was found to decompose to $\mathrm{CuInS}_{2}$ below $260{ }^{\circ} \mathrm{C}$.

Further work with this class of molecules has yielded analogous precursors with desirable properties such as lower melting points (including the liquid precursor $\left.\left(\mathrm{P}^{\mathrm{n}} \mathrm{Bu}_{3}\right)_{2} \mathrm{CuIn}(\mathrm{SEt})_{4}\right)$ and higher solubility in organic solvents. ${ }^{8,37,55}$ In this work, the precursor $\left(\mathrm{PPh}_{3}\right)_{2} \mathrm{CuIn}(\mathrm{SEt})_{4}$ is used in the synthesis of $\mathrm{CuInS}_{2}$ nanoparticles. The analogous compound $\left(\mathrm{PPh}_{3}\right)_{2} \mathrm{CuIn}(\mathrm{SePh})_{4}$ is used in the synthesis of $\mathrm{CuInSe}_{2}$ nanoparticles. The reactions are outlined in Scheme 2. The stepwise method of synthesis, isolating the red intermediate, is required for the purest products. If the precursor is brought directly to 250 or $300{ }^{\circ} \mathrm{C}$, the final black powder is predominantly $\mathrm{CuInS}_{2}$, but impurity peaks are evident in the XRD pattern.

$\mathrm{X}$-ray powder diffraction (fig. 13) clearly shows that pure $\mathrm{CuInS}_{2}$ is the product of the reaction at 250 and $300{ }^{\circ} \mathrm{C}$, and $\mathrm{CuInSe}_{2}$ at 275 and $300{ }^{\circ} \mathrm{C}$. The powder diffraction patterns of the red powders from the $200{ }^{\circ} \mathrm{C}$ reactions exhibit unusual splitting of the (112) peaks into two peaks centered about the expected (112) position; the remaining two peaks $(204 / 220)$ and (116/312) are in their expected positions. In all powder patterns, significant broadening of the diffraction lines is apparent; particle sizes of 2.1, 2.8, and $7.4 \mathrm{~nm}$ are calculated by the Scherrer formula for the 200,250 , and $300{ }^{\circ} \mathrm{C} \mathrm{CuInS}$ powders, and 1.8, 4.4, and $9.8 \mathrm{~nm}$ for the 200,275 , and $300{ }^{\circ} \mathrm{C}$ $\mathrm{CuInSe}_{2}$ powders, respectively. The precise identity of the red-brown materials ( 2 for $\mathrm{S}$ and 2 ' for $\mathrm{Se}$ ) is currently under investigation.

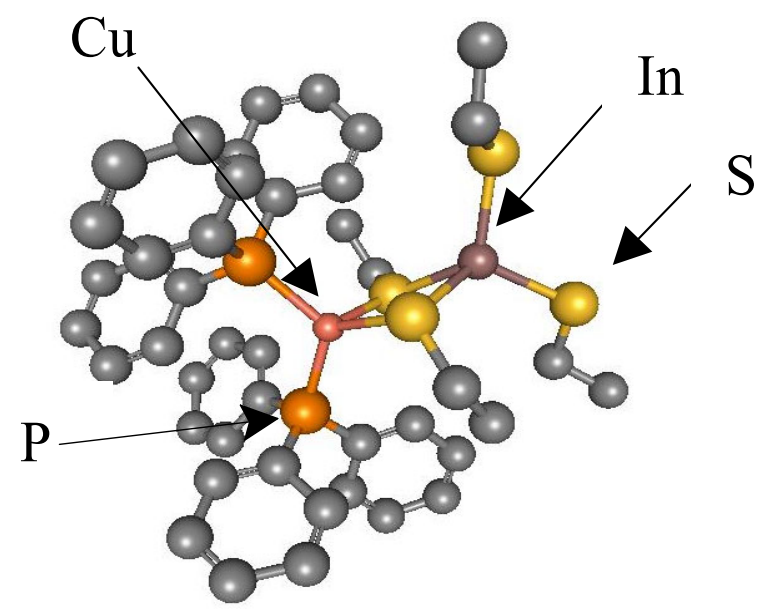

Figure 12.-Molecular structure of $\left(\mathrm{PPh}_{3}\right)_{2} \mathrm{Culn}(\mathrm{SEt})_{4}$. 


\section{SYNTHESIS OF NANOCRYSTALLINE CuInS ${ }_{2}$ AND CulnSe ${ }_{2}$ FROM SINGLE-SOURCE PRECURSORS}

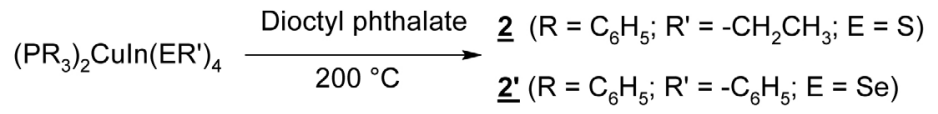

$\underline{\mathbf{2}}$ and $\underline{\mathbf{2}}$ are red-brown powders. Each is washed with toluene and methanol to remove unreacted precursor, dried under vacuum, and stored in a glove box for future use.

$$
\begin{aligned}
& \underline{\mathbf{2}} \underset{250^{\circ} \mathrm{C}}{\stackrel{\text { Dioctyl phthalate }}{\longrightarrow}} \underline{\mathbf{3}} \quad \underline{\mathbf{2}^{\prime}} \underset{275^{\circ} \mathrm{C}}{\stackrel{\text { Dioctyl phthalate }}{\longrightarrow}} \underline{\mathbf{3}}^{\prime} \\
& \underline{\mathbf{2}} \underset{300^{\circ} \mathrm{C}}{\stackrel{\text { Dioctyl phthalate }}{\longrightarrow}} \underline{\mathbf{4}} \quad \underline{\mathbf{2}} \underset{{ }^{\prime}}{\stackrel{\text { Dioctyl phthalate }}{300}} \underline{\mathbf{4}}^{\prime}
\end{aligned}
$$

Scheme 2.- Reaction scheme for the conversion of the single-source precursors to $\mathrm{CulnS}_{2}(\underline{3}$ and $\underline{4})$ and CulnSe $2\left(\underline{3^{\prime}}\right.$ and $\left.\underline{4^{\prime}}\right)$.

(a)

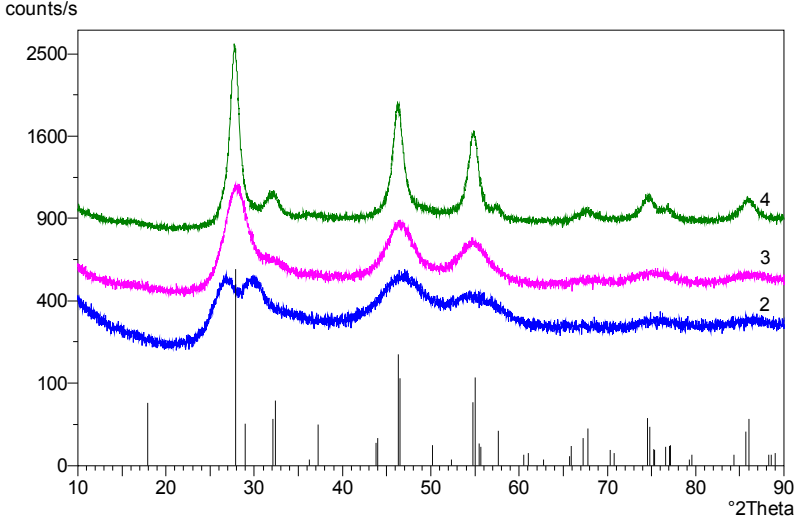

(b)

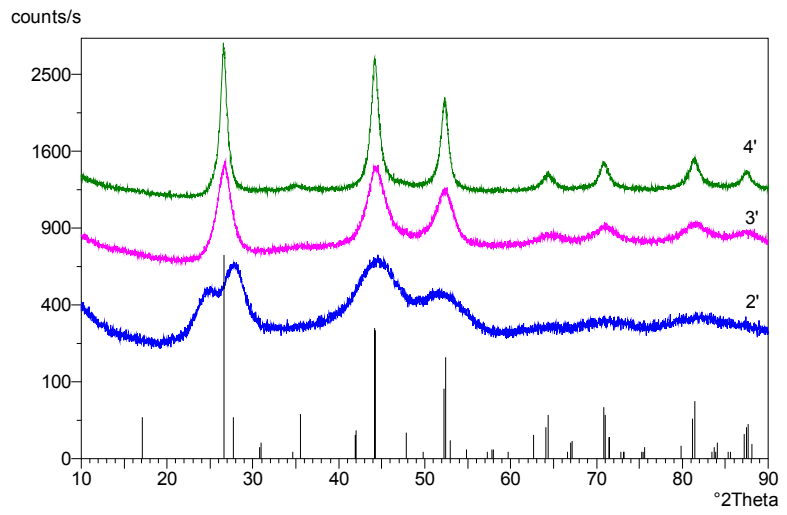

Figure 13.-Powder XRD patterns for a) 2, 3, and 4, the reaction products of $\left(\mathrm{PPh}_{3}\right)_{2} \mathrm{Culn}(\mathrm{SEt})_{4}$ at 200, 250, and $300{ }^{\circ} \mathrm{C}$, and b) 2', 3', and 4', the reaction products of $\left(\mathrm{PPh}_{3}\right)_{2} \mathrm{Culn}(\mathrm{SePh})_{4}$ at 200,275 , and $300^{\circ} \mathrm{C}$.

The powders were examined by scanning and transmission electron microscopies. SEM of all powders shows large spherical particles of $\sim 500 \mathrm{~nm}$ diameter. A typical image is shown in figure 14. At higher resolution, it is seen that the large particles are in fact aggregates of nanoparticles, as seen in figure 15. From the high-resolution transmission electron microscope (HRTEM) images, it appears that the size distribution of the samples is quite large, therefore, the sizes calculated by the Scherrer formula from the X-ray diffraction data are to be taken as only approximate. In conclusion, decomposition of single-source precursors at moderate temperatures affords nanoparticles of $\mathrm{CuInS}_{2}$ and $\mathrm{CuInSe}_{2}$ in good yield. These materials have nanometer-sized dimensions and may find utility in hybrid thin film or quantum dot solar cells. Future work includes altering the surface of the nanoparticles to enable dispersion in solvents, narrowing of the size distributions, and controlling the quantum dot bandgap as a function of size. 
(a)

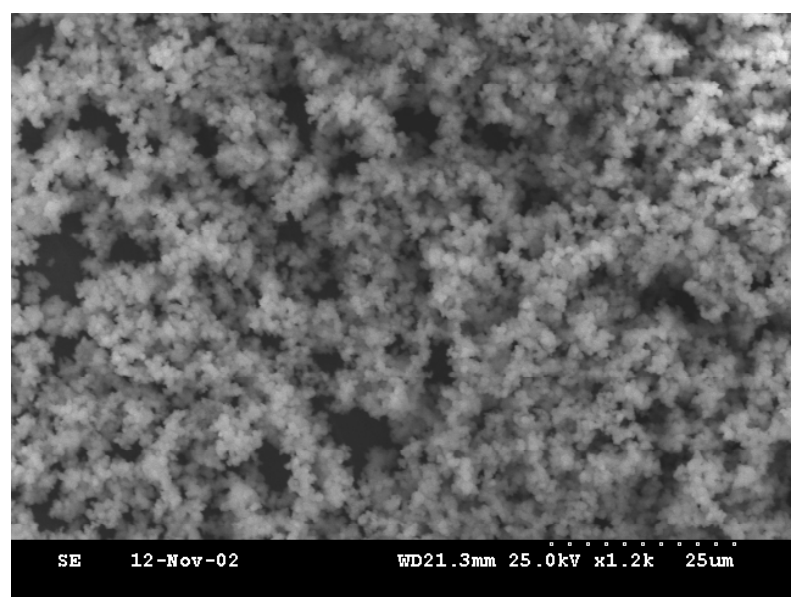

(b)

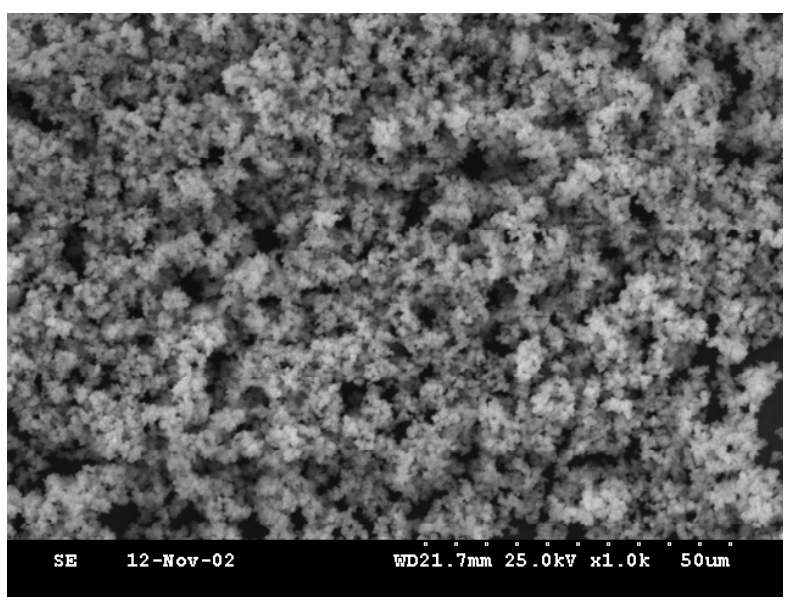

Figure 14.-Scanning electron micrograph images of samples (a) $2\left(\mathrm{CulnS}_{2}\right)$ and (b) $4\left(\mathrm{CulnSe}_{2}\right)$.

(a)

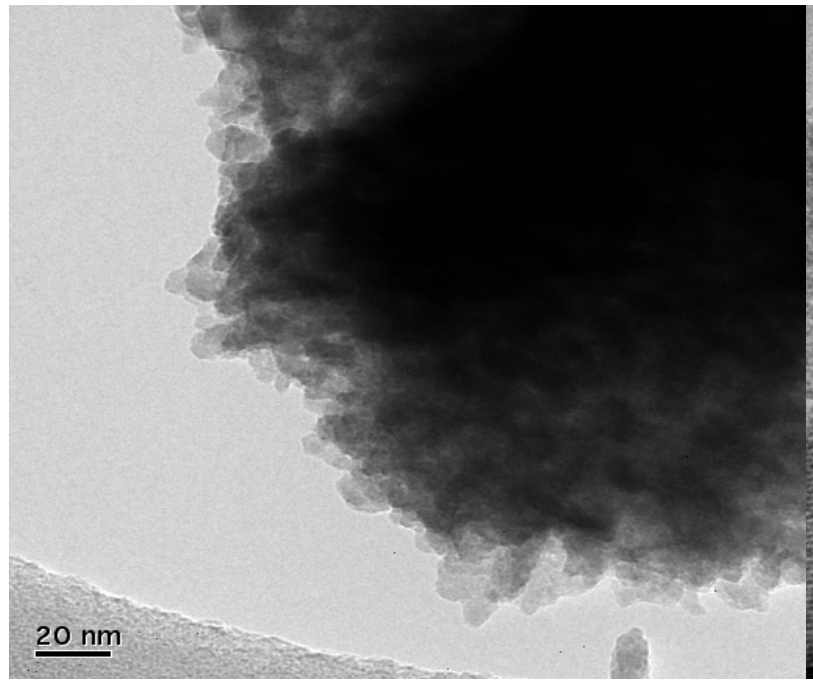

(b)

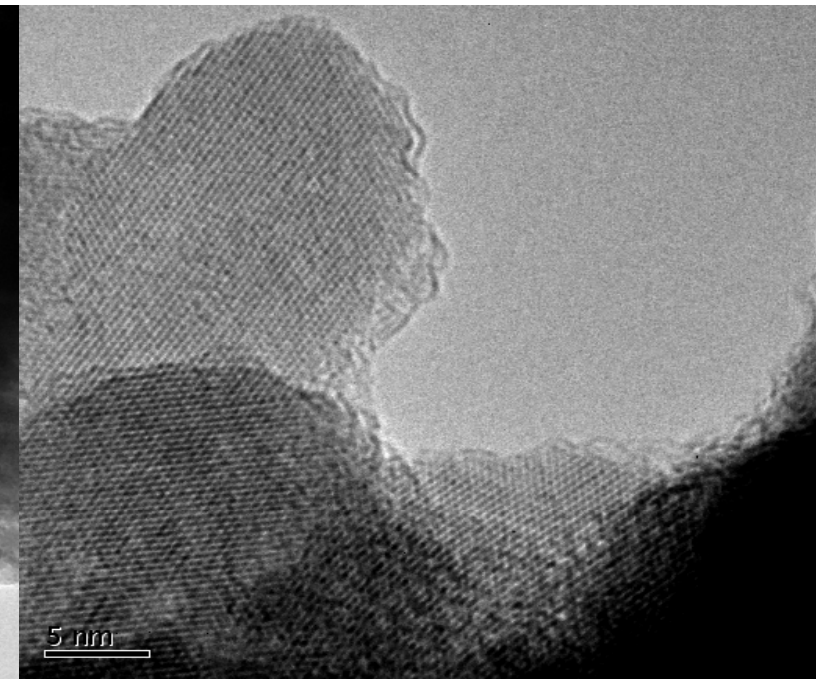

Figure 15.-Medium (a) and high-resolution (b) HRTEM images of sample 4 (CulnSe $)$.

\section{Temperature Dependence of the Performance of Conventional Polymer Solar Cells}

\section{A. Materials Used and Device Design for Solar Cell-Temperature Study at RIT}

In an effort to begin to evaluate the suitability of some of the new hybrid designs for potential space application, we measured temperature dependence of a conventional polymer solar cell which utilized a blend of poly-3 hexylthiophene (fig. 16(a)), chemically modified fullerenes $\left(\mathrm{C}_{60}\right)$ or [6,6]-phenyl-[C61]-butyric acid methyl ester (PCBM) (fig. 16(b)), and purified single wall (carbon) nanotubes (SWNT) (fig. 16(c)), deposited on a poly(3,4ethylenedioxythiophene)/poly(styrene sulfonate) (PEDOT/PSS) polymer thin film, deposited on a indium tin oxide (ITO) coated glass substrate. The synthesis and purification of the SWNT followed the methodology of previous reports. ${ }^{56-58}$ The individual polymer films were deposited by spin coating. Figure 17(a) shows a schematic of the basic cell structure and figure 17(b) show the results film thickness via contact profilometry. 
A series of devices was fabricated with a P3HT to PCBM ratio fixed at 1; the percentage of SWNTs was systematically increased (fig. 18). It was observed that the device performance decreased with increasing SWNT content. Devices with SWNT content above $0.5 \%$ by weight were completely shunted. This could be due to the fact that it is extremely difficult to keep these highly conductive elements from merely providing electron percolation between the Al contact and the PEDOT-PPV layer, possibly directly to the ITO layer. However, there is also the possibility that the SWNT is merely acting as recombination pathways throughout the active region of the device. ${ }^{59}$

\section{B. Performance of Baseline Cells as a Function of Temperature}

The performance of the baseline cells with $0.1 \%$ SWNTs were measured as a function of temperature (see fig. 19). As the temperature was lowered below room temperature a decrease in both the open circuit voltage and short circuit current was measured. This observed positive temperature coefficient for temperatures below room temperature points out the differences that obviously exist between the so-called "soft" solar cell and their more traditional crystalline counterparts. These devices are currently being measured at elevated temperatures and will be presented in a future publication.

(a)

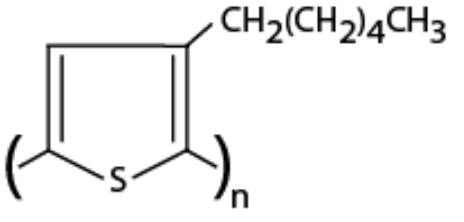

(b)

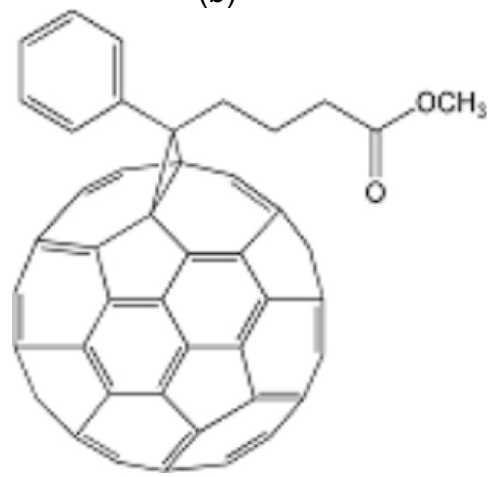

(c)

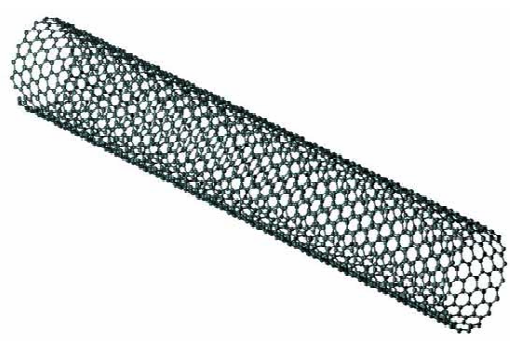

Figure 16.-Schematics of (a) Poly-3-hexylthiophene (P3HT), (b) [6,6]-phenyl-[C61]-butyric acid methyl ester (PCBM); and (c) Single wall carbon nanotube (SWNT), used at RIT to prepare solar cells for temperature study.

(a)

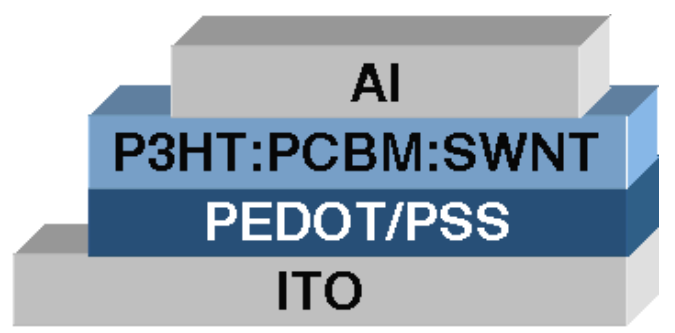

(b)

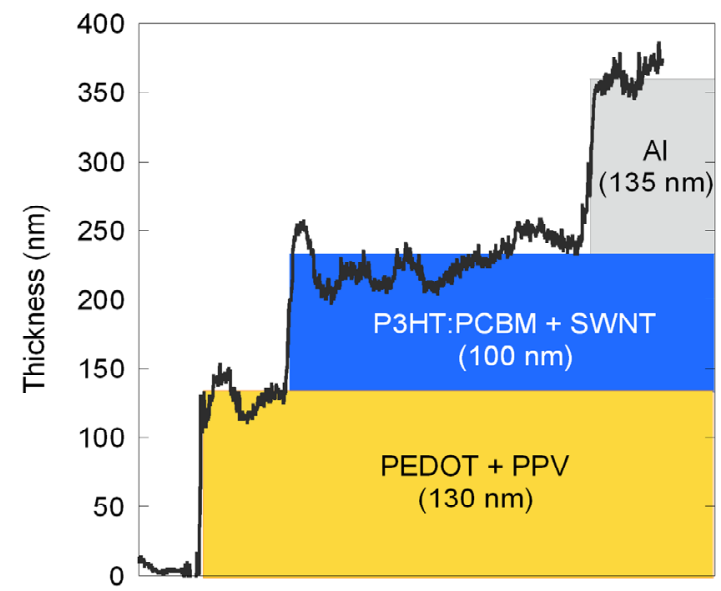

Figure 17.-Schematic of the (a) baseline P3HT:PCBM:SWNT solar cell structure used for temperature study and

(b) a cross-sectional contact profilometry scan of the thickness of the device layers. 


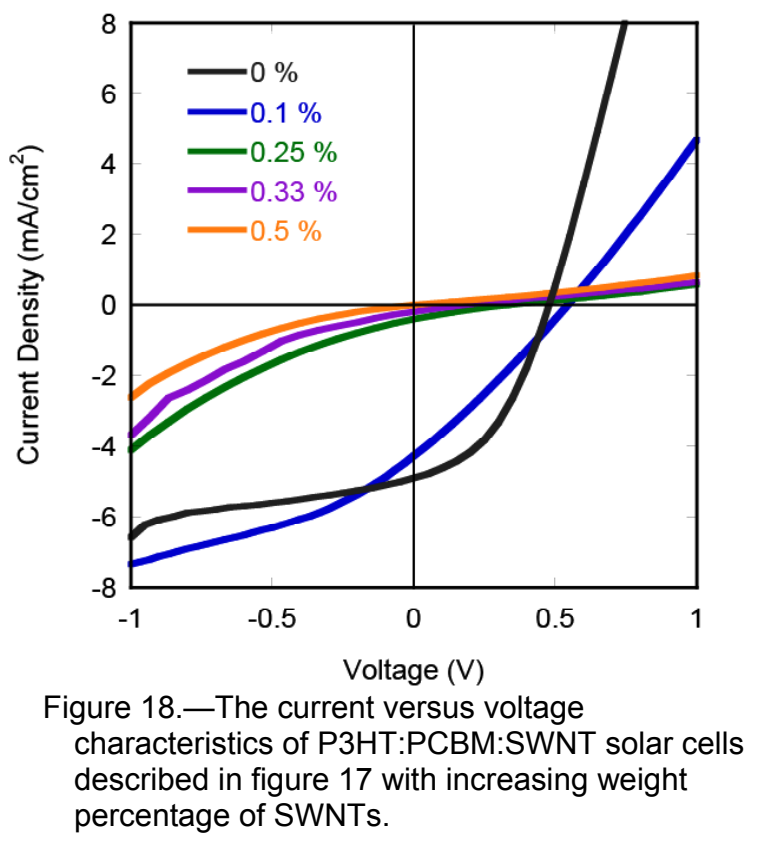

(a)

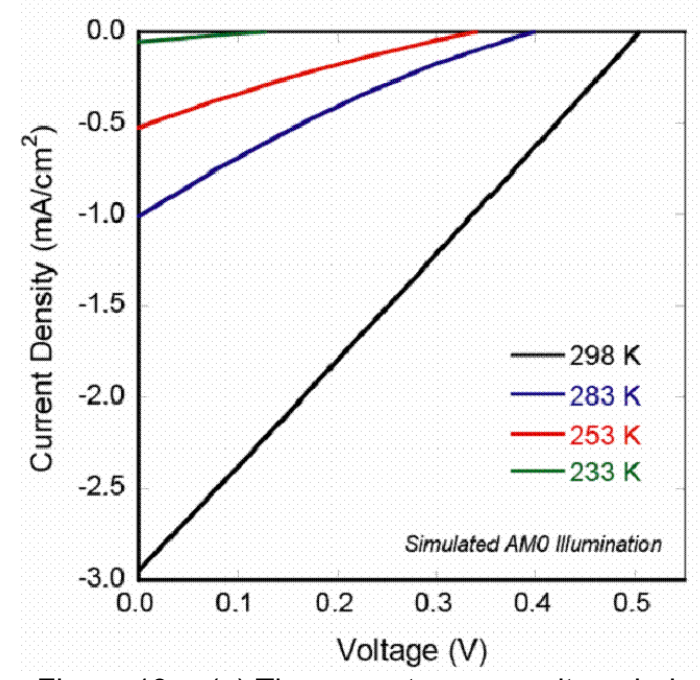

(b)

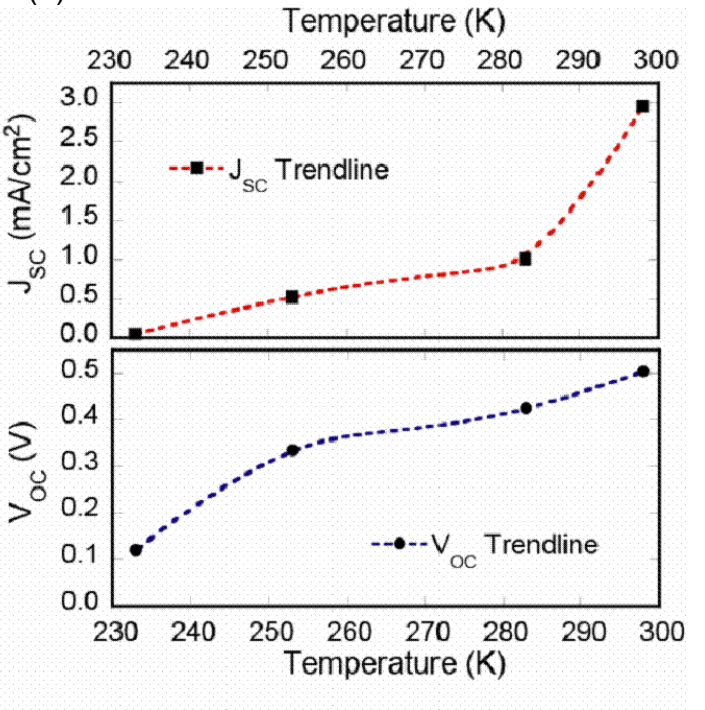

Figure 19.-(a) The current versus voltage behavior of P3HT:PCBM:SWNT (1:1:0.1) cell as a function of temperature and (b) the short circuit current and open circuit voltages as a function of temperature.

In order to investigate the substantial decrease in the photovoltaic performance of these cells as a function of temperature we measured the conductivity of the SWNT materials as a function of temperature. The purified SWNT materials show little or no change in their conductivity over the temperature range over which the cells were measured (see fig. 20). This is possibly due to the various chiralities present in the sample which result in a mixture of semiconducting and metallic nanotubes which can act to cancel out each other's temperature coefficients of resistivity (i.e., negative for semiconducting and positive for metallic). ${ }^{56}$

The current versus voltage performance of the baseline P3HT:PCBM $(1: 1 \mathrm{w} / \mathrm{w})$ devices (no SWNTs) was also measured from 320 to $140 \mathrm{~K}$ under vacuum to investigate if the degradation had an environmental dependency (see fig. 21). In this case the current density also decreased with decreasing temperature while the open circuit voltage increased slightly. The net behavior was still a positive temperature coefficient for the cell efficiency, but it was considerably smaller than that of the cells measured in ambient. The SWNT containing cells were re-measured upon returning to room temperature. The cells showed no hysteresis, albeit for just a single cycle. Therefore, one possible 
explanation is that the large reduction in cell performance with a reduction of temperature of the cells measured in ambient would be due to their interaction with oxygen and moisture.

\section{Impact of the Addition of Carbon Nanotubes}

The problem of shunting of the blend cells with the addition of the carbon nanotubes may be addressed by improved control of the nanotube distribution throughout the device. One method that may prove useful in this regard is to directly deposit or grow the carbon nanotubes onto the substrate. A low pressure chemical vapor deposition system was used to grow MWNT directly on ITO using previously published methods. ${ }^{60,61}$ A scanning electron microscope image of the resulting ordered array of tubes is shown in figure 22.

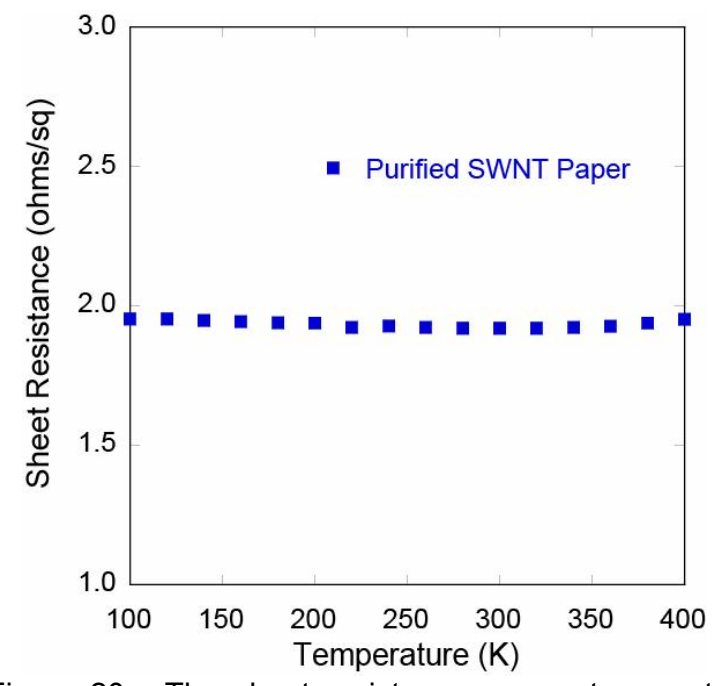

Figure 20.-The sheet resistance versus temperature for a purified single wall carbon nanotube paper.

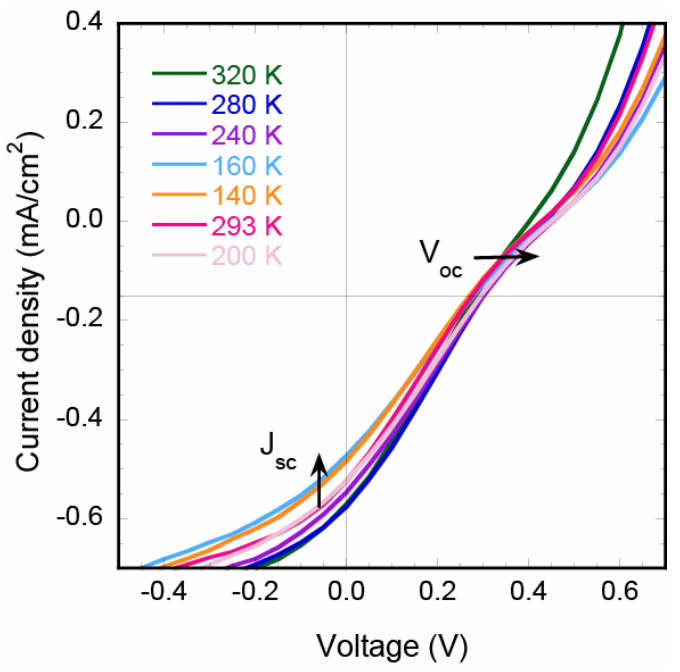

Figure 21.-The current versus voltage behavior of P3HT:PCBM (1:1) cell as a function of temperature.

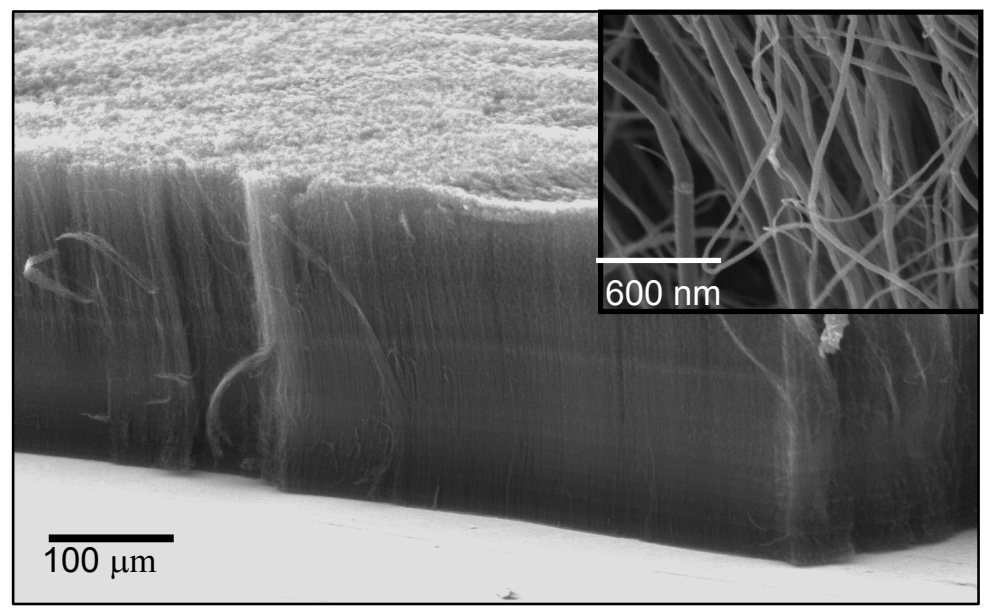

Figure 22.-Scanning electron micrograph of chemical vapor deposited MWNT array on indium tin oxide coated glass. Inset: high-resolution micrograph of the MWNT. 
A higher resolution image of the same film (see fig. 22: inset) show that the film contains a distribution of MWNT diameters. Purity assessments of this array yielded a value for carbonanceous purity at $75 \%$ using a previous establish protocol using Raman spectroscopic studies. ${ }^{61}$ The aligned MWNT arrays were used to produce solar cells using the same P3HT:PCBM one-to-one ration used in the previous devices. Figure 23 shows a digital photograph of the as-deposited MWNT array on indium tin oxide coated glass and a schematic of the basic cell structure.

A series of devices were made using an increasing thickness of MWNT arrays. The spin coating of the polymeric films onto the chemical vapor deposited MWNT arrays was difficult. Figure 24 shows a Nomarski micrograph of the P3HT:PCBM film which was spin coated onto a $275 \mu \mathrm{m}$ thick MWNT array grown on ITO coated glass. This image shows the non-ideal morphology and points out the difficulty in the fabrication methods being employed to produce these types of devices. The use of a PEDOT polymer film between the P3HT:PCBM blend and the MWNT array was found to improve the device morphology and electro-optical characteristics (see fig. 25). However, as was the case with the SWNT containing blends the overall device performance was still less than a conventional P3HT:PCBM device without the addition of carbon nanotubes.

(a)

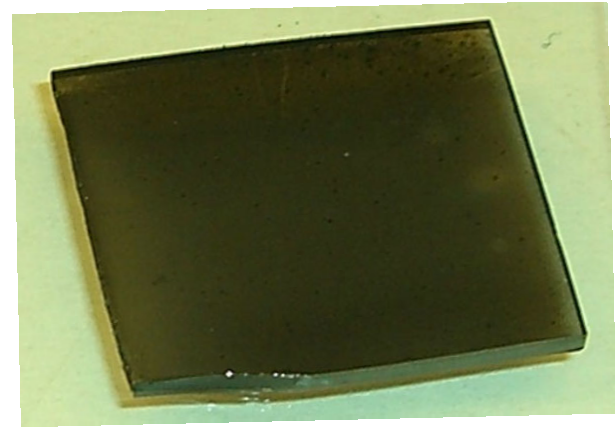

(b)

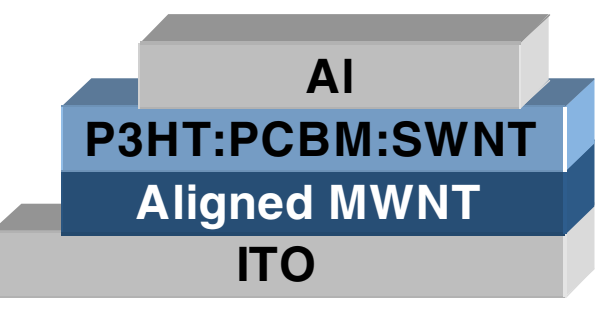

Figure 23.-(a) A digital photograph of the as-deposited MWNT array on indium tin oxide coated glass and (b) a schematic of the basic MWNT cell structure.

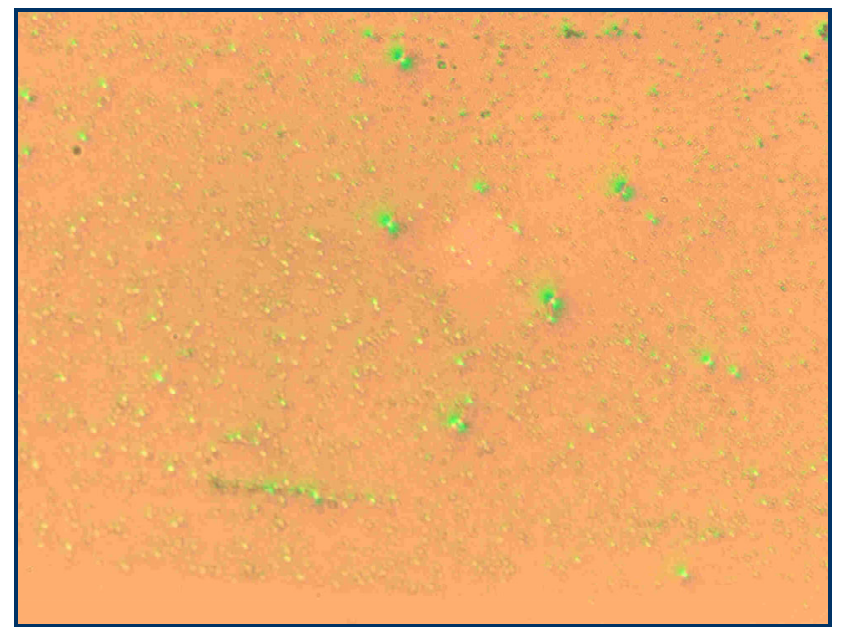

Figure 24.-Nomarski micrograph of a P3HT:PCBM (1:1 ratio) film which was spin coated onto a $275 \mu \mathrm{m}$ thick MWNT array grown on ITO coated glass.

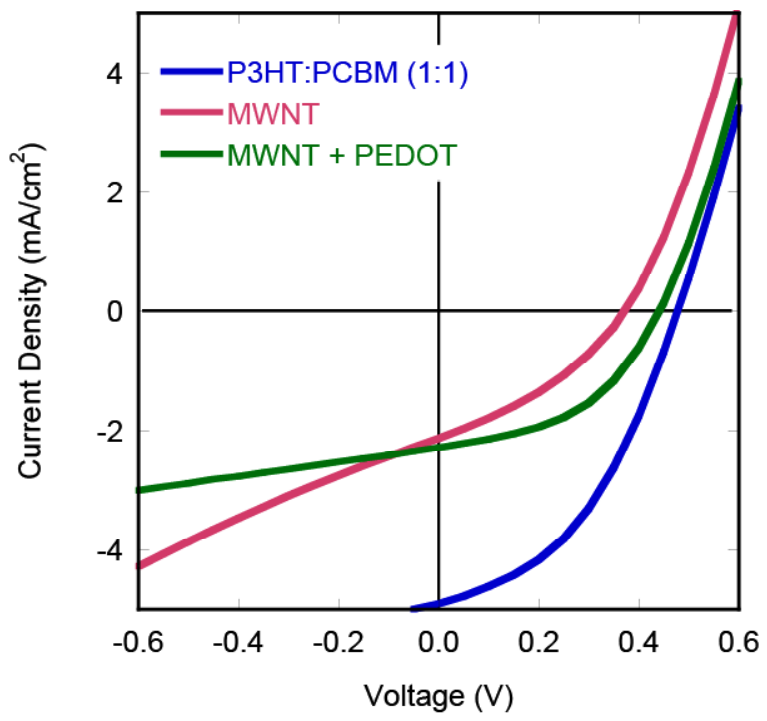

Figure 25.-The current versus voltage behavior of P3HT:PCBM devices deposited directly onto MWNT arrays and with an intermediary PEDOT layer. 


\section{Conclusion}

New thiophene-derivative conjugated polymer thin films with a variable band-gap have been successfully deposited by CVDP for photovoltaic applications. Beyond conventional solution-based polymer synthesis, CVDP allows new monomers and cleaner polymer films with improved optical and materials properties for more stable and efficient devices and for multi-layered electronic devices including multijunction solar cells. A bi-layer heterojunction between $100 \mathrm{~nm}$ thick graphite and $30 \mathrm{~nm}$ thick PITN $(3,6)$ was fabricated; an open circuit voltage of about $300 \mathrm{mV}$ was measured under simulated AM0 conditions. The enhanced carrier mobility of block copolymers is attributed mainly to a smoother carrier transport pathway, which is directly correlated to the block copolymer thin film phase-separated and bi-continuous morphology. Thus, the -DBAB- type of block copolymer is very promising for the development of high efficiency plastic electrical and optoelectronic devices where carrier mobility is critical. Work continues to optimize polymer cells exploiting this materials system at NSU. The EIC/UF team is enlisting the synthetic versatility of organic materials as an approach to "bandgap engineering" of the constituent donor polymers; they are also exploring conjugated polymers with alternating electron rich and electron poor moieties as an approach to bandgap engineering. Photovoltaic cells made from these polymers have not been optimized for uniformity and charge carrier mobility of the polymer layer, so $V_{o c}$ 's have been far less than the theoretical values. There are additional challenges to be overcome in making a multijunction organic polymer PV device. Each cell must be separated by a transparent tunnel junction. The individual cells and metallizations need to be deposited sequentially using a process that does not disturb the underlying layers, in analogy with devices made with inorganic materials. Multijunction devices have led the way in establishing records for efficiency in solar cells employing traditional inorganic semiconductor materials. The first steps have been taken towards applying these concepts to organic photovoltaics, with the prospect of extraordinary power to mass ratios.

A thermal materials study of metallized polymer substrates was undertaken to determine their viability for use in a low temperature solar cell fabrication processes. The main thermal event for the metallized polymer samples upon heating is decomposition, which is found to occur at temperatures of greater then $500{ }^{\circ} \mathrm{C}$. Initial testing of the Upilex (1 mil)/Mo substrates proved difficult since the polymer substrate would curl in the reactor. This problem can be resolved by using a thicker Upilex/Mo substrate, (5 to $10 \mathrm{mil}$ ), and/or metallizing the polymer on both sides. The NASA GRC group has studied the synthesis of potential precursors to $\mathrm{CuInE}_{2}(\mathrm{E}=\mathrm{S}$ or Se). Decomposition of single-source precursors at moderate temperatures affords nanoparticles of $\mathrm{CuInS}_{2}$ and $\mathrm{CuInSe} \mathrm{In}_{2}$ in good yield. These materials have nanometer-sized dimensions and may find utility in hybrid thin film or quantum dot solar cells. Future work includes altering the surface of the nanoparticles to enable dispersion in solvents, narrowing of the size distributions, and controlling the quantum dot bandgap as a function of size. A series of devices was fabricated with a P3HT to PCBM ratio fixed at 1; the percentage of SWNTs was systematically increased. It was observed that the device performance degraded with increasing SWNT content. The performance of the baseline cells with $0.1 \%$ SWNTs were measured as a function of temperature. As the temperature was lowered below room temperature a decrease in both the open circuit voltage and short circuit current was measured. The problem of shunting of the blend cells with the addition of the carbon nanotubes may be addressed by improved control of nanotube distribution throughout the device. One example solution is to directly deposit or grow carbon nanotubes onto substrates.

\section{References}

\footnotetext{
${ }^{1}$ Bailey, S.G., and Flood, D.J., "Space Photovoltaics," Prog. Photovolt. Res. Appl., vol. 6, no. 1, 1998, pp. 1-14.

${ }^{2}$ Sheldon, P., "Process Integration Issues in Thin-Film Photovoltaics and Their Impact on Future Research Directions," Prog. Photovolt. Res. Appl., vol. 8, no. 1, 2000, pp. 77-91.

${ }^{3}$ Guha, S., Yang, J., and Banerjee, A., "Amorphous Silicon Alloy Photovoltaic Research - Present and Future," Prog. Photovolt. Res. Appl., vol. 8, no. 1, 2000, pp. 141-150.

${ }^{4}$ Schock, H.-W., and Noufi, R., "CIGS-Based Solar Cells for the Next Millennium," Prog. Photovolt. Res. Appl., vol. 8, no. 1, 2000, pp. 151-160.

${ }^{5}$ Bonnet, D., and Meyers, P.V., "Cadmium Telluride - Material for Thin Film Solar Cells,” J. Mater. Res., vol. 13, no. 10, 1998, 2740-2753.

${ }^{6}$ Huynh, W.U., Dittmer, J.J., and Alivisatos, A.P., "Hybrid Nanorod-Polymer Solar Cells," Science, vol. 295, no. 5564, 2002, pp. $2425-2428$.

${ }^{7}$ Castro, S.L., Bailey, S.G., Raffaelle, R.P., Banger, K.K., and Hepp, A.F. "Nanocrystalline Chalcopyrite Materials $\left(\mathrm{CuInS}_{2}\right.$ and $\mathrm{CuInSe}_{2}$ ) via Low-Temperature Pyrolysis of Molecular Single-Source Precursors," Chem. Mater., vol. 15, no. 16, 2003, pp.

${ }^{8}$ Banger, K.K., Hollingsworth, J.A., Harris, J.D., Cowen, J., Buhro, W.E., and Hepp, A.F., “Ternary Single-Source Precursors for Polycrystalline Thin-Film Solar Cells," Appl. Organomet. Chem., vol. 16, no. 11, 2002, pp. 617-627.
} 3142-3147. 
${ }^{9}$ Brabec, C.J., Hauch, J.A., Schilinsky, P., and Waldauf, C., "Production Aspects of Organic Photovoltaics and Their Impact on the Commercialization of Devices," MRS Bull., vol. 30, no. 1, 2005, pp. 50-52.

${ }^{10}$ Green, M.A., Emery, K., King, D.L., Hishikawa, Y., and Warta, W. "Solar Cell Efficiency Tables (Version 29)," Prog. Photovolt: Res. Appl., vol. 15, no. 1, 2007, pp. 35-40.

${ }^{11}$ Forrest, S.R., "The Limits to Organic Photovoltaic Cell Efficiency," MRS Bull., vol. 30, no. 1, 2005, pp. $28-32$.

${ }^{12}$ Jin, M.H.-C., and Dai, L., "Vertically Aligned Carbon Nanotubes for Organic Photovoltaic Devices," Organic Photovoltaics: Mechanisms, Materials, and Devices, edited by S.-S. Sun and N.S. Sariciftci, CRC Press, Boca Raton, FL, 2005, pp. 579-597.

${ }^{13}$ Coakley, K.M., Liu, Y., Goh, C., and McGehee, M.D., “Ordered Organic-Inorganic Bulk Heterojunction Photovoltaic Cells," MRS Bull., vol. 30, no. 1, 2005, pp. 37-40.

${ }^{14}$ Sariciftci, N.S., "Plastic Photovoltaic Devices," Materials Today, vol. 7, no. 9, 2004, pp. 36-40.

${ }^{15}$ Fortin, J.B., and Lu, T.-M., Chemical Vapor Deposition Polymerization: The growth and properties of parylene thin films, Kluwer Academic Publishers, Boston, 2004, Chaps. 6, 7.

${ }^{16}$ Winder C., and Sariciftci, N.S., "Low Bandgap Polymers for Photon Harvesting in Bulk Heterojunction Solar Cells," J. Mater. Chem., vol. 14, no. 7, 2004, pp. 1077-1086.

${ }^{17}$ Kim, Y.-G., Thompson, B.C., Ananthakrishnan, N., Padmanaban, G., Ramakrishnan, S., and Reynolds, J.R., "Variable Band Gap Conjugated Polymers for Optoelectronic and Redox Applications," J. Mater. Res., vol. 20, no. 12, 2005, pp. 31883198.

${ }^{18}$ Wudl, F., Kobayashi, M., and Heeger, A.J., "Poly(isothianapthene)," J. Org. Chem., vol. 49, no. 18, 1984, pp. 3382-3384.

${ }^{19}$ Liu, C., Oshima, K., Shimomura, M., and Miyauchi, S., "All Polymer PTC Devices: Temperature-Conductivity Characteristics of Polyisothianaphthene and Poly(3-hexylthiophene) Blends," J. Appl Polymer Sci., vol. 97, no. 5, 2005, pp. $1848-1854$.

${ }^{20}$ Patil, A.O., Heeger, A.J., and Wudl, F., “Optical Properties of Conducting Polymers,” Chem. Rev., vol. 88, no. 1, 1988, pp. $183-200$

${ }^{21}$ Kastner, J., Kuzmany, H., Vegh, D., Landl, M., Cuff, L., and Kertesz, M., "Raman Spectra and Ground State of the New Low Bandgap Polymer Poly(thienopyrazine)," Synth. Met., vol. 69, no. 1-3, 1995, pp. 593-594.

${ }^{22}$ Kim, K., and Jin, J.-I., "Preparation of PPV Nanotubes and Nanorods and Carbonized Products Derived Therefrom," Nano Lett., vol. 1, no. 11, 2001, pp. 631-636.

${ }^{23}$ Kraabel, B., Hummelen, J.C., Vacar, D., Moses, D., Sariciftci, N.S., Heeger, A.J., and Wudl, F., "Subpicosecond Photoinduced Electron Transfer from Conjugated Polymers to Functionalized Fullerenes," J. Chem. Phys., vol. 104, no. 11, 1996, pp. 4267-4273.

${ }^{24}$ Gosztola, D., Wang B., and Wasielewski, M.R., "Factoring Through-Space and Through-Bond Contributions to Rates of Photoinduced Electron Transfer in Donor-Spacer-Acceptor Molecules," J. Photochem. and Photobiol. (A), vol. 102, no. 1, 1997 , pp. 71-80.

${ }^{25}$ Tang, C.W., “Two-Layer Organic Photovoltaic Cell,” Appl. Phys. Lett., vol. 48, no. 2, 1986, pp. $183-185$.

${ }^{26} \mathrm{Yu}$, G., Gao, J., Hummelen, J.C., Wudl, F., and Heeger, A.J., "Polymer Photovoltaic Cells: Enhanced Efficiencies via a Network of Internal Donor-Acceptor Heterojunctions," Science, vol. 270, no. 5243, 1995, pp. 1789-1791.

${ }^{27}$ Boer, B., Stalmach, U., Hutten, P., Melzer, C., Krasnikov, V., and Hadziioannou, G., "Supramolecular Self-Assembly and Opto-Electronic Properties of Semiconducting Block Copolymers," Polymer, vol. 42, no. 21, 2001, pp. 9097-9109.

${ }^{28}$ Sun, S.-S., "Design of a Block Copolymer Solar Cell,” Sol. Energy Mat. Sol. Cells, vol. 79, no. 2, 2003, pp. $257-264$.

${ }^{29}$ Sun, S.-S. and Sariciftci, N.S., (eds.), Organic Photovoltaics: Mechanisms, Materials and Devices, CRC Press, Boca Raton, Florida, 2005, Chaps. 7, 8, and 9.

${ }^{30}$ Chen X.L., and Jenekhe, S.A., "Block Conjugated Copolymers: Toward Quantum-Well Nanostructures for Exploring Spatial Confinement Effects on Electronic, Optoelectronic, and Optical Phenomena," Macromolecules, vol. 29, no. 19, 1996, pp. 6189-6192.

${ }^{31}$ Zhang, C.; Choi, S.; Haliburton, J.; Li, R.; Cleveland, T.; Sun, S.; Ledbetter, A.; Bonner, C.; "Design, Synthesis, and Characterization of a -Donor-Bridge-Acceptor-Bridge- Type Block Copolymer via Alkoxy and Sulfone Derivatized Polyphenylenevinylenes," Macromolecules, vol. 39, no. 13, 2006, pp. 4317-4326.

${ }^{32}$ Sun, S.-S., "Recent Progress of Organic Photovoltaics," Advances in Solar Energy, vol. 17, edited by D.Y. Goswami, Earthscan Publications Ltd., London, 2007, pp. 74-98.

${ }^{33}$ Bao, Z., Dodabalapur, A., and Lovinger, A.J., "Soluble and Processable Regioregular Poly(3-hexylthiophene) for Thin Film Field-Effect Transistor Applications with High Mobility," Appl. Phys. Lett., vol. 69, no. 26, 1996, pp. 4108-4110.

${ }^{34}$ Sun, S.-S., Fan, Z., Wang, Y., and Haliburton, J., "Organic Solar Cell Optimizations," J. Mater. Sci., vol. 40, no. 6, 2005, pp. 1429-1443.

${ }^{35}$ Sun, S.-S., Zhang, C., Ledbetter, A., Choi, S., Seo, K., Bonner, Jr., C.E., Drees, M., and Sariciftci, N.S., "Photovoltaic Enhancement of Organic Solar Cells by a Bridged Donor-Acceptor Block-Copolymer Approach," Appl. Phys. Lett., vol. 90, no. 4, 2007, 043117, 3 pp.

${ }^{36}$ Thompson, B.C., Kim, Y-G., McCarley, T.D., and Reynolds, J.R., "Soluble Narrow Band Gap and Blue Propylenedioxythiophene-Cyanovinylene Polymers as Multifunctional Materials for Photovoltaic and Electrochromic Applications," J. Am. Chem. Soc., vol. 128, no. 39, 2006, pp. 12714-12725. 
${ }^{37}$ Banger, K.K., Jin, M.H.-C., Harris, J.D., Fanwick P.E., and Hepp, A.F., “A New Facile Route for the Preparation of SingleSource Precursors for Bulk, Thin-Film, and Nanocrystallite I-III-VI Semiconductors," Inorg. Chem., vol. 42, no. 24, 2003, pp. 7713-7715.

${ }^{38}$ Hepp, A.F., McNatt, J.S., Dickman, J.E., Banger, K.K., Kelly, C.V., Jin, M.H.-C., Aquino-González, A.R. and Rockett, A., "Aerosol-Assisted Chemical Vapor Deposited Thin Films for Space Photovoltaics," Fourth International Energy Conversion Engineering Conference (IECEC-4), AIAA-2006-4010 (NASA/TM-2006-214445), 14 pp., 2006.

${ }^{39}$ Castro, S.L., Bailey, S.G., Raffaelle, R.P., Banger, K.K., and Hepp, A.F., "Synthesis and Characterization of Colloidal $\mathrm{CuInS}_{2}$ Nanoparticles from a Molecular Single-Source Precursor," J. Phys. Chem B, vol. 108, no. 33, 2004, pp. $12429-12435$.

${ }^{40}$ Hepp, A.F., Bailey, S.G., and Raffaelle, R.P., "Inorganic Photovoltaic Materials and Devices: Past, Present, and Future," Organic Photovoltaics: Mechanisms, Materials and Devices, S.-S. Sun and N.S. Sariciftci, Eds., CRC Press, Boca Raton, FL, 2005, pp. 19-36.

${ }^{41}$ Luque, A., and Martí, A., "Increasing the Efficiency of Ideal Solar Cells by Photon Induced Transitions at Intermediate Levels," Phys. Rev. Lett., vol. 78, no. 26, 1997, pp. 5014-5017.

${ }^{42}$ Eberspacher, C., Pauls, K., and Serra, J., "Non-Vacuum Processing of CIGS Solar Cells," Proceedings of the $29^{\text {th }}$ IEEE Photovoltaics Specialist Conference, Institute of Electrical and Electronic Engineers, Piscataway, NJ, 2002, pp. 684-687.

${ }^{43}$ Grätzel, M., "Perspectives for Dye-Sensitized Nanocrystalline Solar Cells," Prog. Photovolt., vol. 8, no. 1, 2000, pp. 171185.

${ }^{44}$ Klaer, J., Bruns, J., Henninger, R., Töpper, K., Klenk, R., Ellmer, K., and Bräunig, D., “A Tolerant Two Step Process for Efficient CuInS 2 Solar Cells," Proceedings of the $2^{\text {nd }}$ World Conference on Photovoltaic Solar Energy Conversion, vol. I., European Commission, Luxembourg, 1998, pp. 537-540.

${ }^{45}$ Contreras, M.A., Egaas, B., Ramanathan, K., Hiltner, J., Swartzlander, A., Hasoon, F., and Noufi, R., "Progress Toward 20\% Efficiency in $\mathrm{Cu}(\mathrm{In}, \mathrm{Ga}) \mathrm{Se}_{2}$ Polycrystalline Thin-Film Solar Cells,” Prog. Photovolt., vol. 7, no. 4, 1999, pp. 311-316.

${ }^{46}$ Marcinkevičius, S., Leon, R., Čechavičius, B., Siegert, J., Lobo, C., Magness, B., and Taylor, W., "Changes in Carrier Dynamics Induced by Proton Irradiation in Quantum Dots," Physica B, 2002, vol. 314, no. 1-4, pp 203-206.

${ }^{47}$ Walters R.J., Summers, G.P., Messenger, S.R., Freundlich, A., Monier, C., and Newman, F.” Radiation Hard Multi-

Quantum Well InP/InAsP. Solar Cells for Space Applications," Prog. Photovolt., vol. 8, no. 3, 2000, pp. 349-354.

${ }^{48}$ Sobolev, N.A., Cavaco, A., Carmo, M.C., Grundmann, M., Heinrichsdorff, F., and Bimberg, D., "Enhanced Radiation Hardness of InAs/GaAs Quantum Dot Structures," Phys. Stat. Sol B, vol. 224, no. 1, 2001, pp. 93-96.

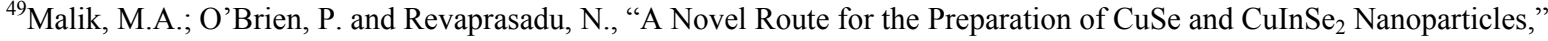
Adv. Mater., vol. 11, no. 17, 1999, pp. 1441-1444.

${ }^{50}$ Czekelius, C., Hilgendorff, M., Spanhel, L., Bedja, I., Lerch, M., Müller, G., Bloeck, U., Su, D.-S., and Giersig, M., “A

Simple Colloidal Route to Nanocrystalline ZnO/CuInS 2 Bilayers," Adv. Mater., vol. 11, no. 8, 1999, pp. $643-646$.

${ }^{51}$ Gurin, V.S., "Nanoparticles of Ternary Semiconductors in Colloids: Low-Temperature Formation and Quantum Size Effects," Coll. Surf. A, vol. 142, no. 1, 1998, pp. 35-40.

${ }^{52} \mathrm{Lu}$, Q., Hu, J., Tang, K., Qian, Y., Zhou, G., and Liu, X., "Synthesis of Nanocrystalline $\mathrm{CuMS}_{2}(\mathrm{M}=\mathrm{In}$ or Ga) through a Solvothermal Process," Inorg. Chem., vol. 39, no. 7, 2000, pp. 1606-1607.

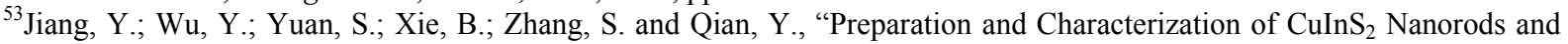
Nanotubes from an Elemental Solvothermal Reaction,” J. Mater. Res., vol. 16, no. 10, 2001, pp. 2805-2809.

${ }^{54}$ Hirpo, W., Dhingra, S., Sutorik, A.C., and Kanatzidis, M.G., "Synthesis of Mixed Copper-Indium Chalcogenolates. SingleSource Precursors for the Photovoltaic Materials CuInQ 2 (Q = S, Se)," J. Am. Chem. Soc., vol. 115, no. 4, 1993, pp.1597-1599.

${ }^{55}$ Banger, K.K., Cowen, J., and Hepp, A.F., "Synthesis and Characterization of the First Liquid Single-Source Precursors for the Deposition of Ternary Chalcopyrite $\left(\mathrm{CuInS}_{2}\right)$ Thin Film Materials," Chem. Mater., vol. 13, no. 11, 2001, pp. $3827-3829$.

${ }^{56}$ Landi, B.J., Cress, C.D., Evans, C.M., and Raffaelle, R.P., "Thermal Oxidation Profiling of Single-Walled Carbon Nanotubes." Chem. Mater., vol. 17, no. 26, 2005, pp. 6819-6834.

${ }^{57}$ Landi, B.J., Ruf, H.J., Evans, C.M., Cress, C.D., and Raffaelle, R.P., "Purity Assessment of Single-Wall Carbon Nanotubes, Using Optical Absorption Spectroscopy," J. Phys. Chem. B, vol. 109, no. 20, 2005, pp. 9952-9965.

${ }^{58}$ Landi, B.J., Ruf, H.J., Worman, J.J., and Raffaelle, R.P., "Effects of Alkyl Amide Solvents on the Dispersion of Single Wall Carbon Nanotubes.” J. Phys. Chem. B, vol. 108, no. 44, 2004, pp. 17089-17095.

${ }^{59}$ Martel, R., Derycke, V., Lavoie, C., Appenzeller, J., Chan, K.K., Tersoff, J., and Avouris, P., “Ambipolar Electrical Transport in Semiconducting Single-Wall Carbon Nanotubes." Phys. Rev. Lett., vol. 87, no. 25, 2001, 256805, 4 pp.

${ }^{60}$ Harris, J.D., Raffaelle, R.P., Gennett, T., Landi, B.J., and Hepp, A.F., "Growth of Multi-Walled Carbon Nanotubes by Injection CVD," Mat. Sci. \& Eng. B, vol. 116, no. 3, pp. 369-374.

${ }^{61}$ DiLeo, R.A.; Landi, B.J.; Raffaelle, R.P., "Purity Assessment of Multiwalled Carbon Nanotubes by Raman Spectroscopy," J. Appl. Phys., vol. 101, no. 6, 2007, 064307, 5 pp. 


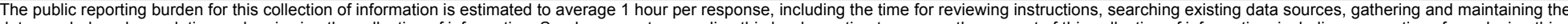

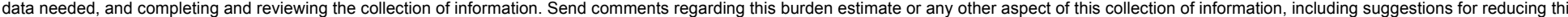

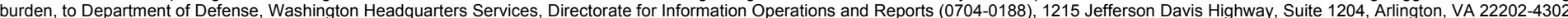

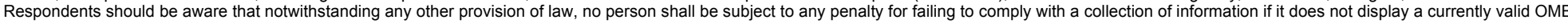
control number.

PLEASE DO NOT RETURN YOUR FORM TO THE ABOVE ADDRESS.

\section{REPORT DATE $(D D-M M-Y Y Y Y)$}

01-12-2007

\section{TITLE AND SUBTITLE}

Ultra-Lightweight Hybrid Thin-Film Solar Cells: A Survey of Enabling Technologies for

Space Power Applications

\section{REPORT TYPE}

Technical Memorandum

6. AUTHOR(S)

Hepp, Aloysius, F.; McNatt, Jeremiah, S.; Bailey, Sheila, G.; Dickman, John, E.; Raffaelle, Ryne, P.; Landi, Brian, J.; Anctil, Annick; DiLeo, Roberta; Jin, Michael, H.-C.; Lee, ChunYoung; Friske, Theresa, J.; Sun, Sam-S.; Zhang, Cheng; Choi, S.; Ledbetter, Abram; Seo, Kang; Bonner, Carl, E.; Banger, Kulbinder, K.; Castro, Stephanie, L.; Rauh, David

7. PERFORMING ORGANIZATION NAME(S) AND ADDRESS(ES)

National Aeronautics and Space Administration

John H. Glenn Research Center at Lewis Field

Cleveland, Ohio 44135-3191

\section{SPONSORING/MONITORING AGENCY NAME(S) AND ADDRESS(ES)}

National Aeronautics and Space Administration

Washington, DC 20546-0001

\section{DISTRIBUTION/AVAILABILITY STATEMENT}

Unclassified-Unlimited

Subject Categories: 25 and 44

Available electronically at http://gltrs.grc.nasa.gov

This publication is available from the NASA Center for AeroSpace Information, 301-621-0390
3. DATES COVERED (From - To)

\section{5a. CONTRACT NUMBER}

5b. GRANT NUMBER

5c. PROGRAM ELEMENT NUMBER

\section{5d. PROJECT NUMBER}

5e. TASK NUMBER

5f. WORK UNIT NUMBER

WBS 698671.01.03.23

8. PERFORMING ORGANIZATION REPORT NUMBER

E-16170

\section{SPONSORING/MONITORS ACRONYM(S) \\ NASA \\ 11. SPONSORING/MONITORING REPORT NUMBER \\ NASA/TM-2007-214955; AIAA-2007-}

4721

\section{SUPPLEMENTARY NOTES}

\section{ABSTRACT}

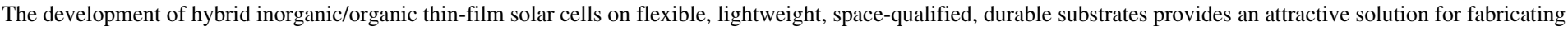

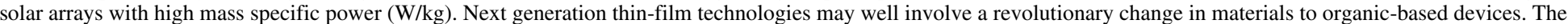

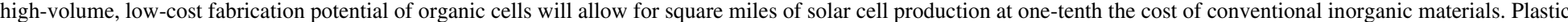

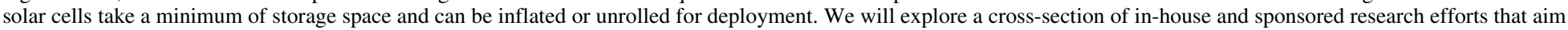

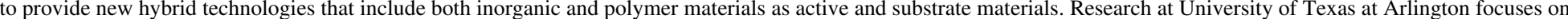

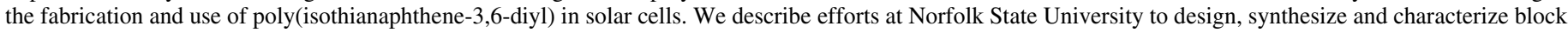

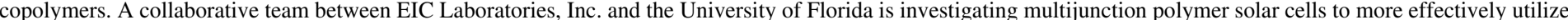

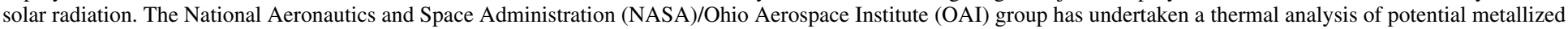

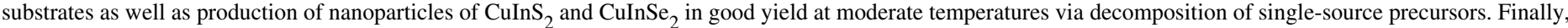

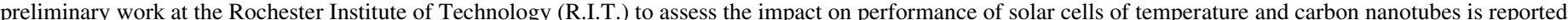

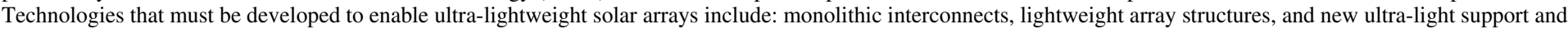

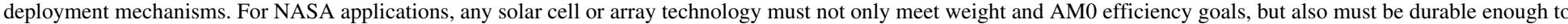
survive launch conditions and space environments.

15. SUBJECT TERMS

Block copolymers; Carbon nanotubes; Chromophores; Copper compounds; Organic semiconductors; Polymers; Quantum dots; Solar cells; Thermal analysis

\section{SECURITY CLASSIFICATION OF:}

a. REPORT

$\mathrm{U}$

\section{b. ABSTRACT} $\mathrm{U}$

\section{LIMITATION OF} ABSTRACT

\section{NUMBER OF} PAGES

29 19a. NAME OF RESPONSIBLE PERSON

STI Help Desk (email:help@sti.nasa.gov)

19b. TELEPHONE NUMBER (include area code) 301-621-0390
UU

\begin{tabular}{l|l} 
PAGE & UU
\end{tabular}

$\mathrm{U}$ 

